\title{
Methyl donor supply to heat stress-challenged polymorphonuclear leukocytes from lactating Holstein cows enhances 1-carbon metabolism, immune response, and cytoprotective gene network abundance
}

\author{
V. Lopreiato, ${ }^{1} \odot$ M. Vailati-Riboni, ${ }^{2} \odot$ C. Parys, ${ }^{3}$ C. Fernandez, ${ }^{4} \odot$ A. Minuti, ${ }^{1} \odot$ and J. J. Loor ${ }^{2 *}$ () \\ ${ }^{1}$ Department of Animal Sciences, Food and Nutrition, Faculty of Agriculture, Food and Environmental Science, \\ Università Cattolica del Sacro Cuore, 29122 Piacenza, Italy \\ ${ }^{2}$ Mammalian NutriPhysioGenomics, Department of Animal Sciences and Division of Nutritional Sciences, University of Illinois, Urbana 61801 \\ ${ }^{3}$ Evonik Nutrition \& Care GmbH, Hanau-Wolfgang 63457, Germany \\ ${ }^{4}$ Animal Science Department, Universitàt Politècnica de Valencia, 46022 Valencia, Spain
}

\begin{abstract}
Mechanisms controlling immune function of dairy cows are dysregulated during heat stress (HS). Methyl donor supply - methionine (Met) and choline (Chol) - positively modulates innate immune function, particularly antioxidant systems of polymorphonuclear leukocytes (PMN). The objective of this study was to investigate the effect of Met and Chol supply in vitro on mRNA abundance of genes related to 1-carbon metabolism, inflammation, and immune function in short-term cultures of PMN isolated from mid-lactating Holstein cows in response to heat challenge. Blood PMN were isolated from 5 Holstein cows $(153 \pm 5 \mathrm{~d}$ postpartum, $34.63 \pm 2.73 \mathrm{~kg} / \mathrm{d}$ of milk production; mean $\pm \mathrm{SD}$ ). The $\mathrm{PMN}$ were incubated for $2 \mathrm{~h}$ at thermal-neutral $\left(37^{\circ} \mathrm{C}\right.$; $\left.\mathrm{TN}\right)$ or heat stress $\left(42^{\circ} \mathrm{C}\right.$; HS) temperatures with 3 levels of Chol $(0,400$, or $800 \mu \mathrm{g} / \mathrm{mL}$ ) or 3 ratios of Lys:Met (Met; 3.6:1, 2.9:1, or 2.4:1). Supernatant concentrations of IL-1 $\beta$, IL-6, and tumor necrosis factor- $\alpha$ were measured via bovinespecific ELISA. Fold-changes in mRNA abundance were calculated separately for Chol and Met treatments to obtain the fold-change response at $42^{\circ} \mathrm{C}(\mathrm{HS})$ relative to $37^{\circ} \mathrm{C}(\mathrm{TN})$. Data were subjected to ANOVA using PROC MIXED in SAS (SAS Institute Inc., Cary, NC). Orthogonal contrasts were used to determine the linear or quadratic effect of Met and Chol for mRNA fold-change and supernatant cytokine concentrations. Compared with PMN receiving $0 \mu \mathrm{g}$ of $\mathrm{Chol} / \mathrm{mL}$, heatstressed PMN supplemented with Chol at 400 or 800 $\mu \mathrm{g} / \mathrm{mL}$ had greater fold-change in abundance of $C B S$, $C S A D, G S S, G S R$, and GPX1. Among genes associated with inflammation and immune function, fold-change in abundance of TLR2, TLR4, IRAK1, IL1B, and IL10
\end{abstract}

Received April 2, 2020.

Accepted July 10, 2020.

*Corresponding author: jloor@illinois.edu increased with 400 and $800 \mu \mathrm{g}$ of $\mathrm{Chol} / \mathrm{mL}$ compared with PMN receiving $0 \mu \mathrm{g}$ of $\mathrm{Chol} / \mathrm{mL}$. Fold-change in abundance of $S A H H$ decreased linearly at increasing levels of Met supply. A linear effect was detected for $M P O, N F K B 1$, and SOD1 due to greater fold-change in abundance when Met was increased to reach Lys: Met ratios of 2.9:1 and 2.4:1. Although increasing Chol supply upregulated $B A X, B C L 2$, and $H S P 70$, increased Met supply only upregulated $B A X$. Under HS conditions, enhancing PMN supply of Chol to $400 \mu \mathrm{g} / \mathrm{mL}$ effectively increased fold-change in abundance of genes involved in antioxidant production (conferring cellular processes protection from free radicals and reactive oxygen species), inflammatory signaling, and innate immunity. Although similar outcomes were obtained with Met supply at Lys:Met ratios of 2.9:1 and 2.4:1, the response was less pronounced. Both Chol and Met supply enhanced the cytoprotective characteristics of PMN through upregulation of heat shock proteins. Overall, the modulatory effects detected in the present experiment highlight an opportunity to use Met and particularly Chol supplementation during thermal stress.

Key words: heat stress, choline, methionine, polymorphonuclear leukocytes (PMN), immunometabolism

\section{INTRODUCTION}

The well-acknowledged hallmark by which heat stress (HS) affects modern dairy cows is reduced feed intake, leading to reduction of nutrient absorption and increased basal metabolism (maintenance requirements) caused by activation of the thermoregulatory system (Bernabucci et al., 2010, 2014). These adaptations, in turn, lead to lower milk production. If the reduction in feed intake represents a form of caloric restriction allowing hyperthermic animals to reduce heat generation (a "survival" mechanism), a reduction of nutrient or 
energy availability inevitably alters systemic physiology, including the immune system (Bernabucci et al., 2010; Aggarwal and Upadhyay, 2013).

Dairy animals under HS have reduced $\mathrm{N}$ intake, increased N losses in sweat (Joshi et al., 1968; Gao et al., 2017), and reduced rumen microbial protein synthesis. The latter leads to reduced portal blood flow and absorption of AA (McGuire et al., 1989; Gao et al., 2017; Hyder et al., 2017). Thus, the indirect effect of HS through a reduction in nutrient intake may cause a shortage in AA supply, which in turn negatively affects the immune response and oxidant status and hampers successful adaptation to hyperthermal conditions. This scenario further emphasizes the concept that proper nutrition (i.e., supply of specific nutrients) could help cows during periods of stress, reducing adverse effects and enhancing recovery (Ingvartsen and Moyes, 2013).

Some studies have investigated how isolated sub-families of leukocytes respond to a heat challenge in vitro. For example, bovine peripheral blood mononuclear cells exposed to high temperatures experience a reduction in proliferation (in response to mitogen stimulation), lifespan, and DNA synthesis capacity (Lacetera et al., 2006, 2009; Catozzi et al., 2020). Regarding PMN, from a functional standpoint, one study with dairy cows reported reduced phagocytosis and oxidative burst when PMN were incubated for $2 \mathrm{~h}$ at $41^{\circ} \mathrm{C}$ compared with $39^{\circ} \mathrm{C}$ (Lecchi et al., 2016). Clearly, physiological responses in the cow to heat stress are multifaceted. Specific to immune cells, Met coupled with choline (Chol) supplementation has been associated with an improvement in PMN responses to in vitro short-term incubations and ex vivo whole-blood LPS stimulation (Vailati-Riboni et al., 2017; Lopreiato et al., 2019). The mechanisms by which supplemental Met and Chol act to modulate the immune response and oxidative stress are linked to 1-carbon metabolism, encompassing 3 pathways that represent an interconnected route through which these nutrients affect molecular events such as protein synthesis via the mechanistic target of rapamycin (mTOR), energy metabolism, and antioxidant synthesis (Coleman et al., 2020).

The general hypothesis behind the current study was that metabolism, immune function, and apoptosis gene networks in isolated PMN challenged with HS in vitro would be altered. Hence, the objective was to investigate the effect of different levels of Met and Chol supply in vitro on transcription regulation in short-term cultures of "heat-challenged" PMN isolated from mid-lactating Holstein cows. The focus was on genes composing networks associated with one-carbon metabolism, cytokines and inflammation signaling, antimicrobial function, pattern recognition, adhesion, and apoptosis.

\section{MATERIALS AND METHODS}

\section{Animal Handling and Blood Sampling}

Five Holstein cows in mid lactation $(153 \pm 5 \mathrm{~d}$ in milk) were selected from the University of Illinois Dairy herd. All cows were in their second parity, and the average milk production in the week of sampling was $34.63 \pm 2.73 \mathrm{~kg} / \mathrm{d}$. Cows were deemed healthy, were not treated during the current lactation, and had an average milk SCC $<100,000$ cells $/ \mathrm{mL}$. Blood was collected from the jugular vein at $0600 \mathrm{~h}$, before feeding, into Vacutainer tubes (BD Vacutainer, Becton Dickinson and Co., Franklin Lakes, NJ), containing 1.5 $\mathrm{mL}$ of ACD solution A (trisodium citrate, $22.0 \mathrm{~g} / \mathrm{L}$; citric acid, $8.0 \mathrm{~g} / \mathrm{L}$; and dextrose $24.5 \mathrm{~g} / \mathrm{L}$ ). Fifteen tubes per animal were collected for a total of 120 to 150 $\mathrm{mL}$ of blood. Blood was immediately placed on ice and transported to the laboratory for immediate isolation of PMN within 40 min from the time of sampling.

\section{PMN Isolation}

The PMN were isolated based on procedures previously described by our group (Abdelmegeid et al., 2017; Lopreiato et al., 2019). Briefly, samples were centrifuged at $600 \times g$ for $30 \mathrm{~min}$ at $4^{\circ} \mathrm{C}$. The plasma, buffy coat, and approximately one-third of the red blood cells were removed and discarded. Twenty-five milliliters of deionized water at $4^{\circ} \mathrm{C}$ was added to lyse red blood cells, followed by addition of $5 \mathrm{~mL}$ of $5 \times \mathrm{PBS}$ at $4^{\circ} \mathrm{C}$ to restore an iso-osmotic environment. Samples were centrifuged at $200 \times g$ for $10 \mathrm{~min}$ at $4^{\circ} \mathrm{C}$ and the supernatants decanted. The pellet was washed with $10 \mathrm{~mL}$ of $1 \times$ PBS and centrifuged for 5 min $(200 \times g$ at $4^{\circ} \mathrm{C}$ ) and the supernatants decanted. Eight milliliters of deionized water at $4^{\circ} \mathrm{C}$ was added, followed by addition of $2 \mathrm{~mL}$ of $5 \times$ PBS at $4^{\circ} \mathrm{C}$. Samples were centrifuged at $500 \times g$ for $5 \mathrm{~min}$ at $4^{\circ} \mathrm{C}$ and the supernatant decanted. Two subsequent washings using $10 \mathrm{~mL}$ of $1 \times$ PBS at $4^{\circ} \mathrm{C}$ were performed with samples centrifuged at $500 \times$ $g$ for $5 \mathrm{~min}$ at $4^{\circ} \mathrm{C}$ and supernatants decanted. The final PMN pellet from the 5 animals were then mixed to obtain a homogeneous pool, washed again with $10 \mathrm{~mL}$ of $1 \times \mathrm{PBS}$ at $4^{\circ} \mathrm{C}$, centrifuged at $500 \times g$ for 5 min at $4^{\circ} \mathrm{C}$, and the supernatant decanted. Before incubation with Met and Chol, a $50-\mu \mathrm{L}$ aliquot of the PMN pool was incubated for $15 \mathrm{~min}$ on ice with $100 \mu \mathrm{L}$ of the primary antibody CH138A solution $(15 \mu \mathrm{g} / \mathrm{mL}$ in $1 \times$ PBS). The aliquot was then washed twice with $2 \mathrm{~mL}$ of $1 \times$ PBS and incubated for another $15 \mathrm{~min}$ on ice, protected from light, with $50 \mu \mathrm{L}$ of secondary antibody solution phycoerythrin $(4 \mu \mathrm{g} / \mathrm{mL}$ in $1 \times \mathrm{PBS})$, and 50 $\mu \mathrm{L}$ of propidium iodide (PI; $50 \mu \mathrm{g} / \mathrm{mL}$ ) before reading 
with a flow cytometer. The PMN were identified by a combination of morphology (forward vs. side scatter plot) and labeling (phycoerythrin-positive cells). From this population, PI-positive cells were deemed dead. The purity and viability of PMN were greater than $90 \%$.

\section{Incubation and Treatments}

The isolated pool of PMN from the 5 cows was diluted to a final concentration of $6 \times 10^{6}$ cells per $\mathrm{mL}$ with warm $\left(37^{\circ} \mathrm{C}\right)$, methionine-free, incubation medium (RPMI-1640, Gibco/Thermo Fisher, Waltham, MA), and $8 \%$ fetal bovine serum (Sigma-Aldrich, St. Louis, MO) previously heat-inactivated. Pooling cells from different donor cows was deemed necessary to obtain a large enough population to be able to perform the experiment with an acceptable number of replicates at a final concentration of $6 \times 10^{6}$ cells per $\mathrm{mL}$ per replicate. From the diluted pool, aliquots of $1 \mathrm{~mL}$ were incubated in 14-mL Falcon tubes (Fisher Scientific, Waltham, MA), with a snap-cap design to allow air flow, and allocated to each experimental group. The PMN were incubated with 3 levels of supplemental Chol (0, 400, or $800 \mu \mathrm{g} / \mathrm{mL}$ ) over the basal level of Chol already present in the medium $(3 \mu \mathrm{g} / \mathrm{mL}$, as choline chloride) and 3 ratios of Lys:Met (Met; 3.6:1, 2.9:1, or 2.4:1) calculated based on medium concentration of Lys. Actual levels of the $2 \mathrm{AA}$ in the medium were $40 \mathrm{mg} / \mathrm{L}$ for Lys in all treatment groups, and 11.11, 13.79, and 16.67 $\mathrm{mg} / \mathrm{L}$ for Met. The choice of Chol and Met doses used have been discussed in detail in our previous work with PMN (Abdelmegeid et al., 2017; Lopreiato et al., 2019; Vailati-Riboni et al., 2019). Briefly, the choline supply level at $400 \mu \mathrm{g} / \mathrm{mL}$ was selected based on theoretical delivered metabolizable choline via supplementation of a rumen-protected commercially available product at the time of the experiment (Zhou et al., 2016b), whereas the choline supply level at $800 \mu \mathrm{g} / \mathrm{mL}$ was then added as a double dose. The Lys:Met ratios of 3.6:1 and 2.9:1 mimic those in the MP content of typical corn silage-based diets not supplemented with rumenprotected Met (NRC, 2001) and diets supplemented with rumen-protected Met to reach an approximately 3:1 ratio that has been shown to improve overall lactation performance (Armentano et al., 1997; Osorio et al., 2014; Zanton et al., 2014; Zhou et al., 2016b; Batistel et al., 2017). The Lys:Met ratio of 2.4:1 was selected to test whether additional Met would elicit or limit a PMN response. The PMN were then incubated for 2 $\mathrm{h}$ at $37^{\circ} \mathrm{C}$ (thermo-neutral, $\mathbf{T N}$ ) or $42^{\circ} \mathrm{C}$ (heat stress, HS) in a sterile incubator with a controlled $\mathrm{CO}_{2}(5 \%)$ atmosphere. We selected $42^{\circ} \mathrm{C}$ to simulate conditions of whole-body hyperthermia, which can be detected when dairy cows experience HS (Silanikove, 2000), whereas the length of incubation was the same as our previous experiments with PMN (Lopreiato et al., 2019; VailatiRiboni et al., 2019). Each treatment was carried out in triplicate. Both L-methionine (Sigma-Aldrich) and Chol, as choline chloride (Sigma-Aldrich), were added to the test tubes from stock solution previously prepared using the incubation medium as a diluent.

\section{RNA Extraction}

After incubation, PMN were pelleted by centrifugation and the supernatant collected for further analysis. Total RNA was extracted using Qiazol reagent (Qiagen, Hilden, Germany). The cell pellet was placed in $1 \mathrm{~mL}$ of Qiazol and tissue was homogenized with a Bead Beater 16 (Biospec, Bartlesville, OK) using two 30-s cycles of the homogenizer at full speed and placed on ice after homogenization for $1 \mathrm{~min}$. Homogenized samples were spun to remove any remaining cell debris. Chloroform was then added to the homogenized sample, centrifuged at $16,000 \times g$ for $15 \mathrm{~min}$ at $4^{\circ} \mathrm{C}$, and the aqueous phase removed carefully. Precipitation of RNA was achieved with the addition of ethanol (Decon Labs Inc., King of Prussia, PA), and the subsequent RNA pellet was washed and cleaned using miRNeasy mini spin columns (Qiagen). Genomic DNA was removed during purification with on-column DNase digestion (Qiagen). The concentration of RNA was measured using a NanoDrop ND-1000 spectrophotometer (NanoDrop Technologies, Wilmington, DE), and RNA quality was assessed using a 2100 Bioanalyzer (Agilent Technologies, Santa Clara, CA). All samples had an RNA integrity value greater than 8.0.

\section{cDNA Synthesis and Quantitative PCR}

Genes selected for transcript profiling (Table 1) in PMN were those associated with methionine cycle (ALDH7A1, BHMT, CHDH, MAT1A, MAT2A, MTR, $P E M T, S A H H)$, the transsulfuration pathway and antioxidant system (CBS, CDO1, CSAD, CTH, GCLC, $G P X 1, G S R, G S S)$, cytokines and inflammation signaling (IL1B, IL10, IL6, IRAK1, NFKB1, NR3C1), antimicrobial function, pattern recognition, and adhesion (CXCR1, HLAA, LYZ, MPO, SELL, SOD1, TLR2, TLR 4), and apoptosis and cellular stress (BAX, $B C L 2, H S P 70)$. Sequence information for all primers used can be found elsewhere (Fear and Hansen, 2011; Abdelmegeid et al., 2017). A portion of the RNA was diluted to $100 \mathrm{ng} / \mu \mathrm{L}$ using DNase-/RNase-free water before reverse transcription. Then, cDNA was synthesized using $100 \mathrm{ng}$ of RNA, $1 \mu \mathrm{g}$ of dT18 (Operon Biotechnologies, Huntsville, AL), $1 \mu \mathrm{L}$ of $10 \mathrm{mmol} / \mathrm{L}$ 
dNTP mix (Invitrogen Corp., Carlsbad, CA), $1 \mu \mathrm{L}$ of random primers (Invitrogen Corp.), and $10 \mu \mathrm{L}$ of $\mathrm{DN}-$ ase-/RNase-free water. The mixture was incubated at $65^{\circ} \mathrm{C}$ for $5 \mathrm{~min}$ and kept on ice for $3 \mathrm{~min}$. A total of $6 \mu \mathrm{L}$ of master mix composed of $4.5 \mu \mathrm{L}$ of $5 \times$ First-Strand Buffer, $1 \mu \mathrm{L}$ of $0.1 M$ dithiothreitol (DTT), $0.25 \mu \mathrm{L}$ (50 U) of SuperScript III RT (Invitrogen Corp.), and $0.25 \mu \mathrm{L}$ of RNase Inhibitor (10 U, Promega, Madison, WI) was added. The reaction was performed in an Eppendorf Mastercycler Gradient (Eppendorf, Hamburg, Germany) using the following temperature program: $25^{\circ} \mathrm{C}$ for $5 \mathrm{~min}, 50^{\circ} \mathrm{C}$ for $60 \mathrm{~min}$, and $70^{\circ} \mathrm{C}$ for $15 \mathrm{~min}$. The cDNA was then diluted 1:4 (vol:vol) with DNase-/ RNase-free water.

Quantitative PCR (qPCR) was performed using 4 $\mu \mathrm{L}$ of diluted cDNA combined with $6 \mu \mathrm{L}$ of a mixture composed of $5 \mu \mathrm{L}$ of SYBR Green master mix (Applied Biosystems), $0.4 \mu \mathrm{L}$ each of $10 \mu M$ forward and reverse primers, and $0.2 \mu \mathrm{L}$ of DNase-/RNase-free water in a MicroAmp Optical 384-Well Reaction Plate (Applied Biosystems). Each sample was run in triplicate and a 6-point relative standard curve plus the no-template control were used. The reactions were performed in an ABI Prism 7900 HT SDS instrument (Applied Biosys-

Table 1. Target genes investigated in PMN cultures isolated from mid-lactating dairy cows and cultured at thermal-neutral $\left(37^{\circ} \mathrm{C}, \mathrm{TN}\right)$ or heat stress $\left(42^{\circ} \mathrm{C}, \mathrm{HS}\right)$ temperatures for $2 \mathrm{~h}$ with different levels of Met and Chol supply

\begin{tabular}{|c|c|}
\hline $\begin{array}{l}\text { Gene } \\
\text { symbol }\end{array}$ & Gene name \\
\hline $\begin{array}{l}A L D H^{r} A 1 \\
M T R\end{array}$ & $\begin{array}{l}\text { Aldehyde dehydrogenase } 7 \text { family member A1 } \\
\text { 5-Methyltetrahydrofolate-homocysteine } \\
\text { methyltransferase }\end{array}$ \\
\hline$S A H H$ & S-Adenosylhomocysteine hydrolase \\
\hline$C B S$ & Cystathionine $\beta$-synthase \\
\hline$C D O 1$ & Cysteine dioxygenase \\
\hline$C S A D$ & Cysteine sulfinic acid decarboxylase \\
\hline$C T H$ & Cystathionine gamma-lyase \\
\hline$G C L C$ & Glutamate-cysteine ligase catalytic subunit \\
\hline GPX1 & Glutathione peroxidase 1 \\
\hline$G S R$ & Glutathione reductase \\
\hline GSS & Glutathione synthase \\
\hline IRAK1 & Interleukin 1 receptor associated kinase 1 \\
\hline NFKB1 & Nuclear factor kappa B subunit 1 \\
\hline NR3C1 & Glucorticoid receptor \\
\hline$I L 1 B$ & Interleukin 1 beta \\
\hline IL10 & Interleukin 10 \\
\hline$T N F$ & Tumor necrosis factor alpha \\
\hline$C X C R 1$ & $\mathrm{C}-\mathrm{X}-\mathrm{C}$ motif chemokine receptor 1 \\
\hline$H L A A$ & Major histocompatibility complex, class I, A \\
\hline$L Y Z$ & Lysozyme \\
\hline$M P O$ & Myeloperoxidase \\
\hline SELL & Selectin L \\
\hline SOD1 & Superoxide dismutase 1 \\
\hline TLR2 & Toll-like receptor 2 \\
\hline TLR4 & Toll-like receptor 4 \\
\hline$B A X$ & BCL2 associated $\mathrm{X}$, apoptosis regulator \\
\hline BCL2 & Apoptosis regulator \\
\hline HSP70 & Heat shock protein 70 \\
\hline
\end{tabular}

Journal of Dairy Science Vol. 103 No. 11, 2020 tems) using the following conditions: 2 min at $50^{\circ} \mathrm{C}, 10$ min at $95^{\circ} \mathrm{C}$, and 40 cycles of $15 \mathrm{~s}$ at $95^{\circ} \mathrm{C}$ (denaturation) and $1 \mathrm{~min}$ at $60^{\circ} \mathrm{C}$ (annealing + extension). The presence of a single PCR product was verified by the dissociation protocol using incremental temperatures to $95^{\circ} \mathrm{C}$ for $15 \mathrm{~s}$ plus $65^{\circ} \mathrm{C}$ for $15 \mathrm{~s}$. Data were calculated with the 7900 HT Sequence Detection Systems Software (version 2.2.1, Applied Biosystems). The final data were normalized using the geometric mean of 3 internal control genes: GAPDH, RPS9, and UXT. These internal control genes were previously confirmed as suitable for PMN gene expression analysis (Moyes et al., 2014) and have been used in our published studies (Abdelmegeid et al., 2017; Lopreiato et al., 2019). Expression of BHMT, CHDH, MAT1A, and PEMT was undetectable.

\section{Supernatant Analysis}

The collected supernatant was used for analysis of IL-1 $\beta$, IL-6, and tumor necrosis factor (TNF)- $\alpha$ concentrations. Quantification was performed via bovinespecific ELISA kits according to the manufacturers' specifications (IL-1 $\beta$ and IL-6, ThermoFisher Scientific; TNF- $\alpha$, Kingfisher Biotech Inc., St. Paul, MN). For IL-1 $\beta$, IL-6, and TNF- $\alpha$, the intra-assay coefficients of variation $(\mathrm{CV})$ were $4.35 \pm 1.16,7.24 \pm 2.19$, and 3.5 \pm 2.05 , respectively, and the inter-assay CV were 9.49 $\pm 5.92,12.8 \pm 6.13,8.75 \pm 5.22$, respectively.

\section{Statistical Analysis}

The response in mRNA abundance of PMN in HS versus $\mathrm{TN}$ conditions was calculated using fold-change values [(mRNA abundance at HS - mRNA abundance at TN)/mRNA abundance at TN]. Statistical analysis of both mRNA fold-change values and supernatant cytokine data was performed in SAS (ver. 9.4, SAS Institute Inc., Cary, NC). Data were subjected to ANOVA and analyzed using the MIXED procedure. For mRNA fold-change values, data were analyzed using a model that included Lys:Met ratio (3.6:1, 2.9:1, 2.4:1) or Chol supply $(0,400$, or $800 \mu \mathrm{g} / \mathrm{mL})$ as fixed effects. For supernatant cytokines, fixed effects considered were Chol or Met and incubation temperature (Temp; 37 or $42^{\circ} \mathrm{C}$ ). Normality of residuals was tested via PROC UNIVARIATE in SAS. All observations were normally distributed. The Kenward-Roger statement was used for computing the denominator degrees of freedom. Orthogonal contrasts were used to determine the linear or quadratic effect of Met and Chol for mRNA foldchange and supernatant cytokines data. Differences were considered significant at $P \leq 0.05$ and tendencies at $P \leq 0.10$ using the PDIFF statement in SAS. 


\section{RESULTS}

\section{Choline Effect on PMN Cultures During Heat Stress Challenge}

Among genes related to the methionine cycle, transsulfuration pathway, and antioxidant system (Figure 1), a Chol effect was detected for $A L D H^{\prime} 7 A 1, M T R$, $C B S, C D O 1, C S A D, G C L C, G S S, G S R$, and GPX1 genes $(P \leq 0.10)$. Compared with $0 \mu \mathrm{g}$ of $\mathrm{Chol} / \mathrm{mL}$, heat-stressed PMN supplemented with Chol at 400 or $800 \mu \mathrm{g} / \mathrm{mL}$ had greater fold-change in abundance of ALDH"A1, MTR, CBS, CSAD, GSS, GSR, and GPX1 (Chol; $P<0.05$; Figure 1). Choline supply at 400 and $800 \mu \mathrm{g} / \mathrm{mL}$ led to both linear and quadratic effects for ALDH7A1 $(P \leq 0.05), \operatorname{MTR}(P<0.05)$, GSS $(P<$ $0.05), G S R(P<0.05)$, and $G P X 1(P \leq 0.10)$ because of the similar responses obtained for both 400 and 800 $\mu \mathrm{g} / \mathrm{mL}$ (Figure 1).

There was a linear and quadratic effect of Chol (Chol, Lin, and Quad; $P<0.05$ ) for the fold-change in abundance of $C B S$, where PMN incubated with $400 \mu \mathrm{g} /$ $\mathrm{mL}$ had greater fold-change in abundance $(P<0.05)$ and increasing supply to $800 \mu \mathrm{g} / \mathrm{mL}$ caused a lower fold-change compared with $400 \mu \mathrm{g} / \mathrm{mL}$. However, foldchange in abundance at $800 \mu \mathrm{g} / \mathrm{mL}$ remained greater compared with that of $0 \mu \mathrm{g}$ of $\mathrm{Chol} / \mathrm{mL}(P<0.05)$. A similar response was obtained for CSAD (Chol, Lin, and Quad; $P<0.05$ ), where incubation with 400 or $800 \mu \mathrm{g} / \mathrm{mL}$ led to upregulation during HS and greater fold-change in abundance compared with $0 \mu \mathrm{g}$ of $\mathrm{Chol} /$ $\mathrm{mL}$ (Figure 1). Abundance of CDO1 and GCLC had a quadratic effect due to Chol supply $(P<0.05)$. In fact, supplying $400 \mu \mathrm{g} / \mathrm{mL}$ Chol to PMN resulted in greater fold-change in abundance compared with $0 \mu \mathrm{g}$ of $\mathrm{Chol} / \mathrm{mL}(P<0.05)$, whereas increasing to $800 \mu \mathrm{g} /$ $\mathrm{mL}$ downregulated abundance compared with $400 \mu \mathrm{g} /$ $\mathrm{mL}(P<0.05)$, reaching levels similar to $0 \mu \mathrm{g}$ of Chol/ $\mathrm{mL}(P>0.05)$.

Among genes related to inflammation and immune response, fold-change in abundance of NFKB1, SOD1, $M P O$, and $H L A A$ increased linearly with Chol supply (Chol and Lin; $P<0.05$; Figure 2) during HS, with the greatest response observed at $800 \mu \mathrm{g}$ of $\mathrm{Chol} / \mathrm{mL}$. Foldchange in abundance of TLR2, TLR 4, IRAK1, NR3C1, $I L 1 B, I L 10$, and $L Y Z$ was affected by Chol $(P<0.05$; Figure 2) with both linear and quadratic effects (overall, $P \leq 0.10)$. In all cases, compared with $0 \mu \mathrm{g} / \mathrm{mL}(P$ $<0.05)$, increasing Chol supply to 400 and $800 \mu \mathrm{g} / \mathrm{mL}$ led to upregulation. It is noteworthy that compared with that at $400 \mu \mathrm{g}$ of $\mathrm{Chol} / \mathrm{mL}$, the fold-change in abundance was lower at $800 \mu \mathrm{g}$ of $\mathrm{Chol} / \mathrm{mL}$ for TLR2, TLR4, and IRAK1 $(P<0.05)$ and similar for NR3C1, $I L 1 B, I L 10$, and $L Y Z(P>0.05)$. In addition to the overall effect of Chol supply $(P<0.05)$, a quadratic effect was detected for CXCR 1 and SELL $(P<0.05$; Figure 2), where the highest fold-change in abundance was detected at $400 \mu \mathrm{g}$ of $\mathrm{Chol} / \mathrm{mL}$. However, at $800 \mu \mathrm{g}$ of $\mathrm{Chol} / \mathrm{mL}$, fold-change in abundance of $S E L L$ reached similar values to $0 \mu \mathrm{g}$ of $\mathrm{Chol} / \mathrm{mL}(P>0.05)$, whereas fold-change in abundance of $C X C R 1$ at $800 \mu \mathrm{g}$ of Chol/ $\mathrm{mL}$ was lower $(P<0.05)$.

\section{Choline Effect on Cytokine Production}

The levels of IL-1 $\beta$, IL-6, and TNF- $\alpha$ were deemed detected (i.e., within the lower and upper detection limits) in all replicates for each Chol supply level within heat treatments. No statistical effects were detected for Chol $(P>0.05)$ or the interaction Chol $\times$ Temp $(P>$ 0.05; Table 2). However, an overall effect of Temp was observed for IL-1 $\beta$ and IL-6 concentrations $(P<0.05)$, where HS challenge led to overall lower concentrations of these cytokines. There was an overall tendency $(P=$ 0.09) for a linear effect of Chol supply on IL-6 (Table 2 ) with increasing concentrations. In addition, both linear and quadratic effects of Chol supply were observed during HS challenge $(P<0.05)$, mainly caused by the increase of IL-6 at $800 \mu \mathrm{g}$ of $\mathrm{Chol} / \mathrm{mL}$ compared with 0 or $400 \mu \mathrm{g}$ of $\mathrm{Chol} / \mathrm{mL}$. A tendency for a quadratic response of Chol supply in PMN incubated at TN temperature was also detected for TNF- $\alpha(P=0.08$; Table $2)$.

\section{Methionine Effect on PMN Cultures During Heat Stress Challenge}

Among the genes investigated within the methionine cycle, transsulfuration pathway, and antioxidant system, there was an effect of Met supply on fold-change in abundance of $S A H H(P<0.05), C D O 1(P<0.05)$, and $C S A D(P=0.10$; Figure 3$)$. Fold-change in abundance of $S A H H$ decreased linearly $(P<0.05)$ at increasing levels of Met supply. A tendency for both linear and quadratic effects was observed for fold-change in abundance of $C S A D$ (Lin, $P=0.08$; Quad, $P=0.06)$, where a Lys:Met ratio of 2.4:1 led to greater fold-change in abundance compared with 2.9:1 $(P=0.09)$ but similar values relative to $3.6: 1(P>0.05)$.

Among genes related to inflammation and immune response (Figure 4), fold-change in abundance of $M P O$ (tendency, $P=0.09)$, HLAA $(P<0.05)$, and NFKB1 $(P=0.09)$ was affected by Met supply. There was a linear effect for $M P O(P<0.05)$, NFKB1 $(P<0.05)$, and $S O D 1(P=0.09)$ with fold-change in abundance increasing linearly when Met supply increased to reach a Lys:Met ratio of 2.9:1 and 2.4:1. Fold-change in abun- 
dance of $H L A A$ also had a linear and quadratic response (Lin, $P=0.06$; Quad, $P<0.05$ ) caused mainly by the increase with ratios of Lys:Met of 2.9:1 and 2.4:1 compared with 3.6:1 $(P<0.05)$. However, compared with Lys:Met of 2.9:1, fold-change in abundance at Lys: Met ratio of 2.4:1 was lower $(P<0.05)$. Fold-change in abundance of $I L 10$ also was characterized by a tendency for a quadratic response $(P=0.08)$ at increasing levels of Met supply. In addition, a quadratic trend was observed for fold-change in abundance of $C X C R 1(P=$ $0.07)$, where a Lys:Met ratio of 2.9:1 led to lower values compared with 3.6:1 and 2.4:1.
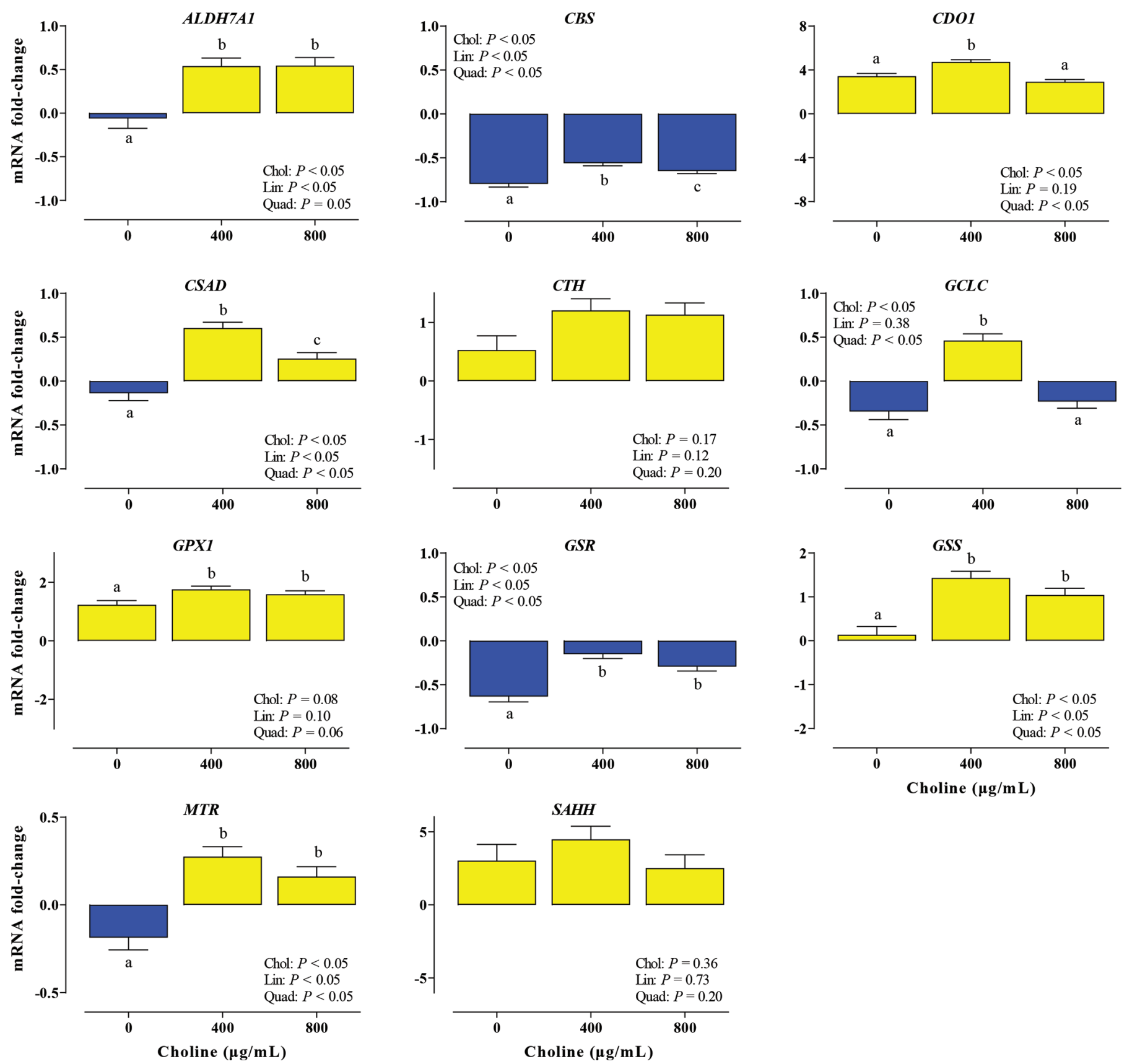

Figure 1. Effect of different in vitro levels of choline (Chol; 0,400 , and $800 \mu \mathrm{g} / \mathrm{mL}$ ) during a heat stress challenge $\left(42^{\circ} \mathrm{C}\right.$, HS) on mRNA abundance of genes related to Met cycle, transsulfuration pathway, and the antioxidant system ( $A L D H 7 A 1, C B S, C D O 1, C S A D, C T H, G C L C$, GPX1, GSR, GSS, MTR, and SAHH) in PMN cultures isolated from mid-lactating dairy cows. Data are expressed as fold-change relative to a thermo-neutral temperature $\left(37^{\circ} \mathrm{C}, \mathrm{TN}\right)$. Yellow bars indicate upregulation, whereas blue bars indicate downregulation due to HS challenge within each treatment relative to TN. Error bars represent SEM of the model estimate. Means with different letters $(\mathrm{a}-\mathrm{c})$ differ at $P \leq 0.10$. 

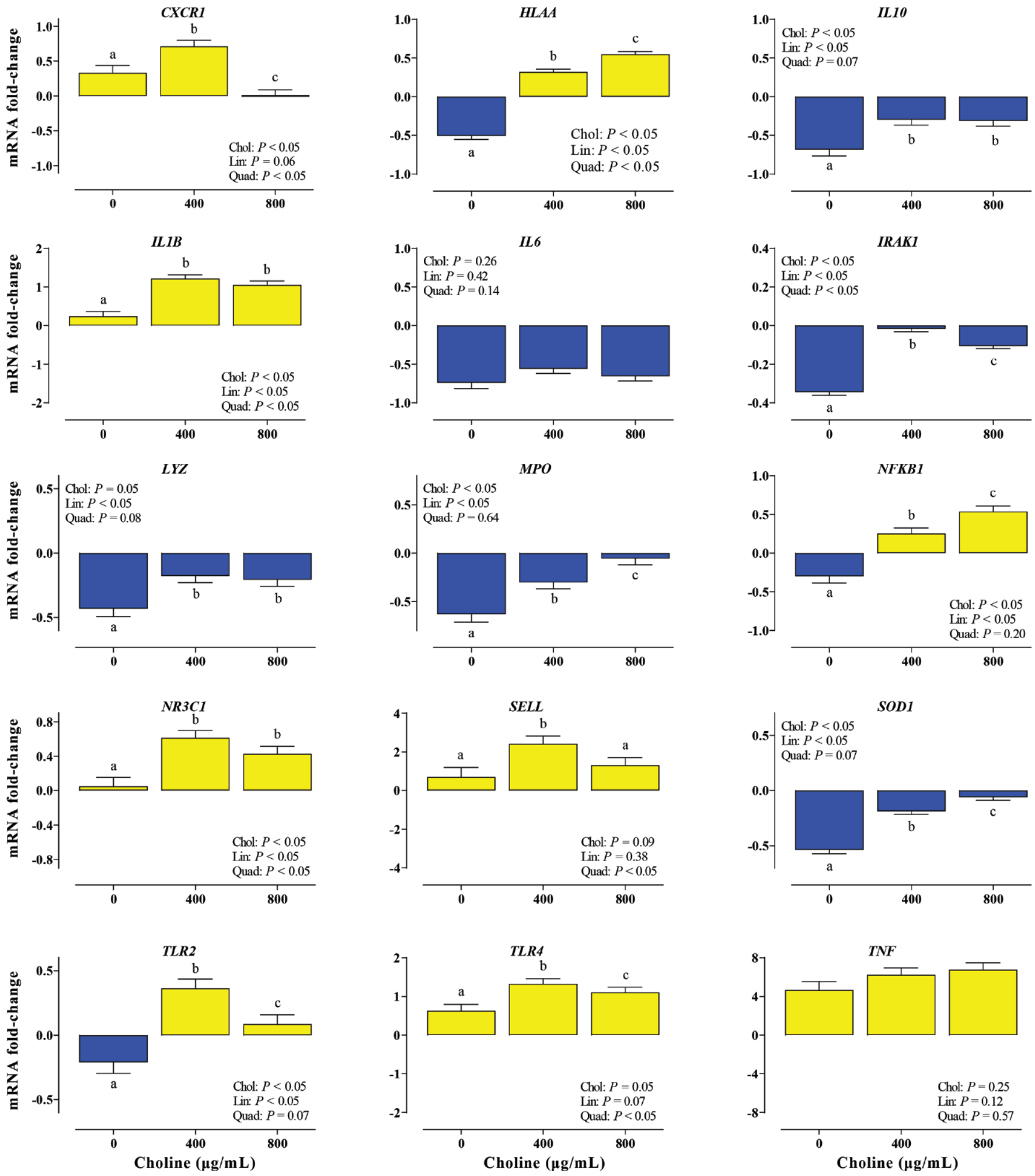

Figure 2. Effect of different in vitro levels of choline (Chol; 0, 400, and $800 \mu \mathrm{g} / \mathrm{mL}$ ) during a heat stress challenge $\left(42^{\circ} \mathrm{C}\right.$, HS) on mRNA abundance of genes related to cytokine mediators, inflammatory response, antimicrobial function, pattern recognition, and adhesion (CXCR1, HLAA, IL10, IL1B, IL6, IRAK1, LYZ, MPO, NFKB1, NR3C1, SELL, SOD1, TLR2, TLR4, and TNF) in PMN cultures isolated from midlactating dairy cows. Data are expressed as fold-change relative to a thermo-neutral temperature $\left(37^{\circ} \mathrm{C}\right.$, TN $)$. Yellow bars indicate upregulation, whereas blue bars indicate downregulation due to HS challenge within each treatment relative to TN. Error bars represent SEM of the model estimate. Means with different letters $(\mathrm{a}-\mathrm{c})$ differ at $P \leq 0.10$. 


\section{Methionine Effect on Cytokine Production}

Concentrations of IL-1 $\beta$, IL-6, and TNF- $\alpha$ were deemed detectable in all replicates for each Met supply level within heat treatment. The overall supernatant concentration of IL-6 (Table 3) was affected by Met $(P$ $<0.05$ ), with increasing production of this cytokine at increasing levels of Met supply (Lin, $P=0.06$ ). Concentrations were similar at 2.4:1 and 2.9:1 Lys:Met but higher compared with that at 3.6:1 (Quad, $P<0.05$ ). There was a trend for a linear reduction of IL-1 $1 \beta$ concentration (Table 2) when Met supply increased in HS PMN cultures $(P=0.10)$. A quadratic effect was also detected for TNF- $\alpha(P<0.05)$ in PMN cultures at TN temperature and for IL-6 $(P<0.05)$ in PMN cultures during HS. For both cytokines, the highest concentrations were detected at a Lys:Met ratio of 2.9:1 (Table $3)$.

\section{Effect of Chol and Met on Apoptosis and Cellular Stress Genes During Heat Stress}

Overall, Chol supply affected fold-change in abundance of $B A X, B C L 2$, and $H S P^{r} 0(P<0.05$; Figure $5)$. A linear increase of fold-change in abundance of $B A X$ (Lin, $P<0.05$ ) was detected due to Chol supply with the highest values at 400 and $800 \mu \mathrm{g}$ of $\mathrm{Chol} / \mathrm{mL}$. Abundance of BCL2 and HSPrO had both linear $(P<$ $0.05)$ and quadratic effects $(P \leq 0.06)$, with the highest values for both genes detected at 400 and $800 \mu \mathrm{g}$ of $\mathrm{Chol} / \mathrm{mL}$ (Figure 5).

In contrast to Chol, the supply of Met only affected fold-change in abundance of $B A X(P<0.05$; Figure $5)$, with a tendency for a linear $(P=0.10)$ and a significant quadratic effect $(P<0.05)$. The fold-change in abundance increased from a Lys: Met ratio of 3.6:1 to $2.9: 1$, but at $2.4: 1$, the fold-change in abundance was similar to that at both $3.6: 1$ and 2.9:1 $(P>0.05)$. In addition, despite an overall effect of Met, fold-change in abundance of $H S P 70$ increased linearly (Figure 5 ) when Met supply increased from a ratio of 3.6:1 to 2.4:1 (Lin, $P=0.06)$.

\section{DISCUSSION}

The immune function of lactating and dry cows appears dysregulated during HS. For instance, proliferation of immune cells, migration of lymphocytes to the udder, and cell viability are the most affected (i.e., suppressed) functions upon an HS challenge (Lacetera et al., 2006; do Amaral et al., 2011; Catozzi et al., 2020). However, relatively few studies have directly addressed the effects of HS on nonspecific immune functions, which are the first line of defense against invading pathogens 


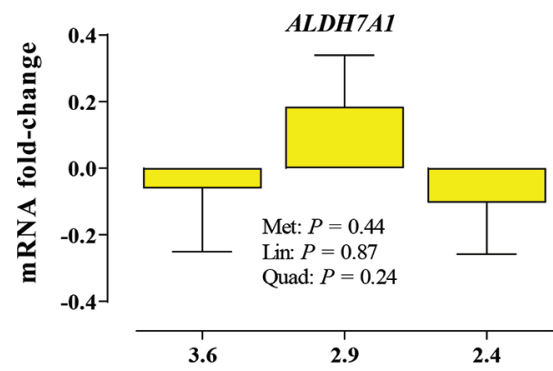

$C S A D$
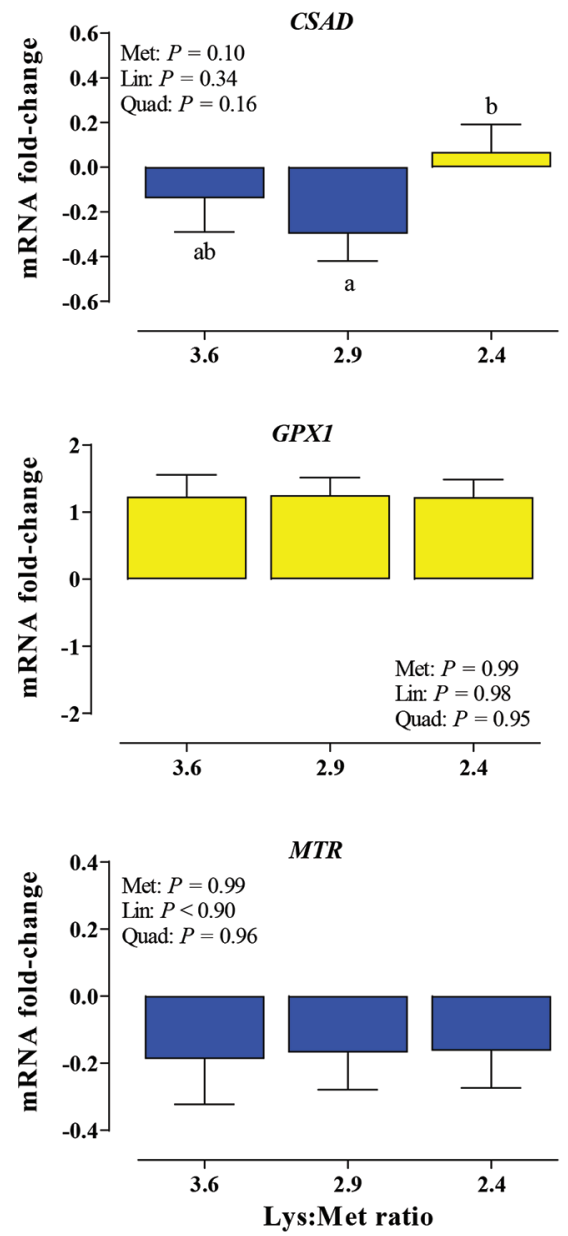

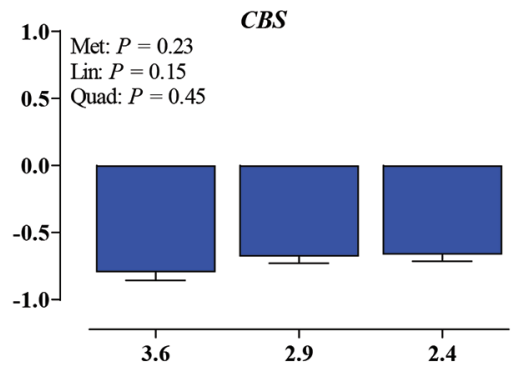

CTH

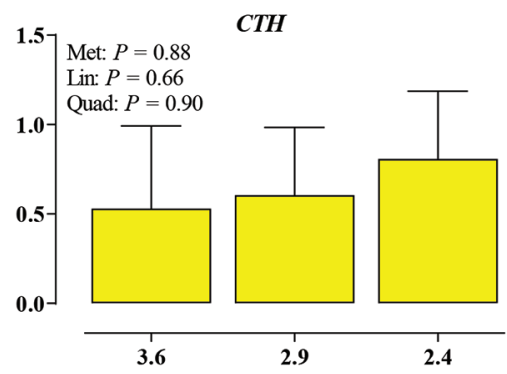

GSR

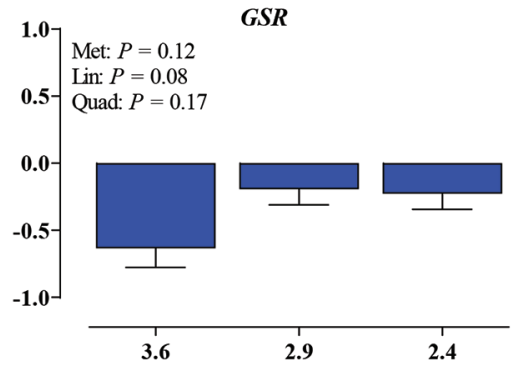

SAHH

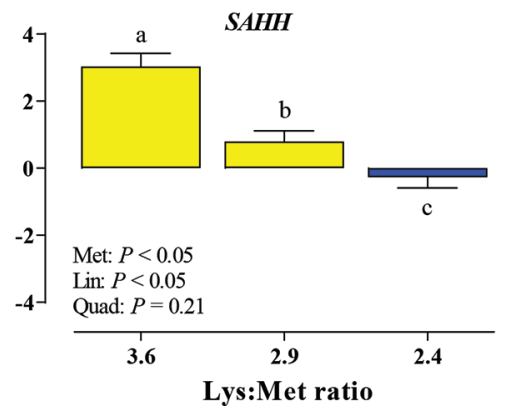

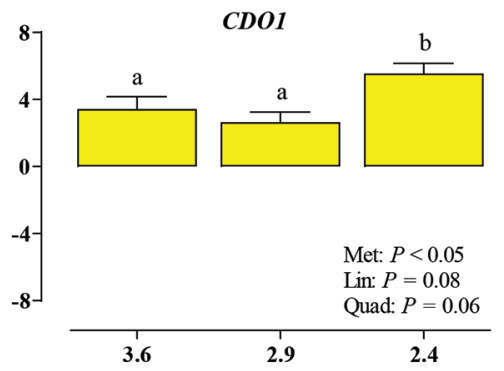

$G C L C$

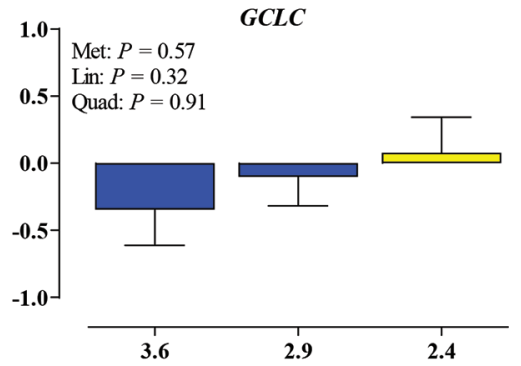

GSS

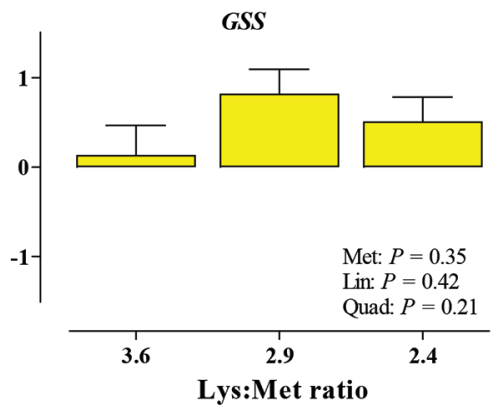

Figure 3. Effect of different in vitro Lys:Met ratios (Met; 3.6:1, 2.9:1, and 2.4:1) during a heat stress challenge $\left(42^{\circ} \mathrm{C}\right.$, HS) on mRNA abundance of genes related to Met cycle, transsulfuration pathway, and antioxidant system ( $A L D H 7 A 1, C B S, C D O 1, C S A D, C T H, G C L C, G P X 1$, GSR, GSS, MTR, and $S A H H$ ) in PMN cultures isolated from mid-lactating dairy cows. Data are expressed as fold-change relative to a thermoneutral temperature $\left(37^{\circ} \mathrm{C}, \mathrm{TN}\right)$. Yellow bars indicate upregulation, whereas blue bars indicate downregulation due to HS challenge within each treatment relative to TN. Error bars represent SEM of the model estimate. Means with different letters $(\mathrm{a}-\mathrm{c})$ differ at $P \leq 0.10$.

(Kobayashi and DeLeo, 2009; Futosi et al., 2013). Body temperatures above $41^{\circ} \mathrm{C}$ have been reported in heatstressed dairy cows and goats (Baumgard and Rhoads, 2013; Salama et al., 2014). Thus, our choice to induce HS with a temperature of $42^{\circ} \mathrm{C}$ mimicked conditions of whole-body hyperthermia and was in accordance with previous experiments using bovine cells (Collier et al., 2006; Lacetera et al., 2006; Salama et al., 2019). Despite normal rectal temperature of dairy cows reaching values of approximately 38 to $39^{\circ} \mathrm{C}$, the thermo-neutral temperature of $37^{\circ} \mathrm{C}$ (basal control) was within physiological conditions and in accordance with standardized cell culture methods (including bovine cell culture). Thus, the current experiment aimed to generate novel insights into the molecular responses to HS challenge of isolated PMN subjected to short-term incubations with differ- 

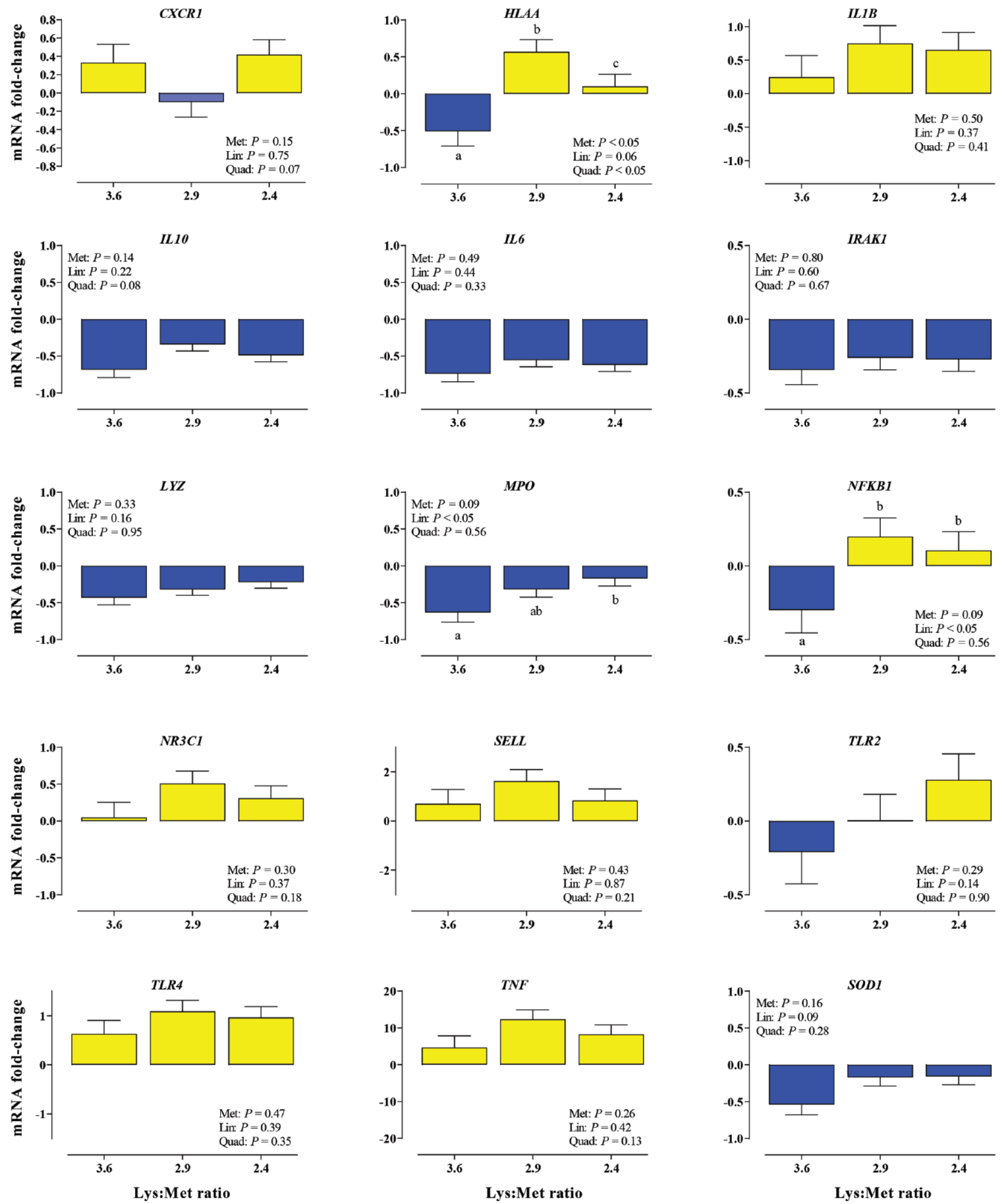

Figure 4. Effect of different in vitro Lys:Met ratios (Met; 3.6:1, 2.9:1, and 2.4:1) during a heat stress challenge $\left(42^{\circ} \mathrm{C}\right.$, HS) on mRNA abundance of genes related to cytokine mediators, inflammatory response, antimicrobial function, pattern recognition, and adhesion (CXCR1, HLAA, IL1B, IL10, IL6, IRAK1, LYZ, MPO, NFKB1, NR3C1, SELL, TLR2, TLR4, TNF, and SOD1) in PMN cultures isolated from mid-lactating dairy cows. Data are expressed as fold-change relative to a thermo-neutral temperature $\left(37^{\circ} \mathrm{C}, \mathrm{TN}\right)$. Yellow bars indicate upregulation, whereas blue bars indicate downregulation due to HS challenge within each treatment relative to TN. Error bars represent SEM of the model estimate. Means with different letters $(\mathrm{a}-\mathrm{c})$ differ at $P \leq 0.10$ 


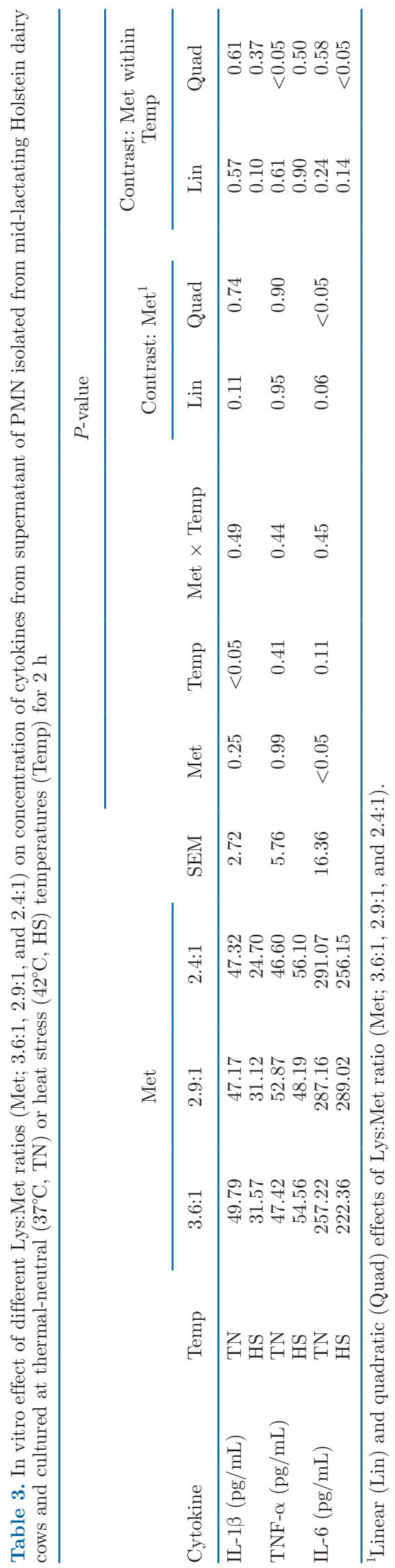

ent levels of Met or Chol. These nutritionally important methyl donors positively modulate in vivo and in vitro innate immune function, particularly the antioxidant system in the transsulfuration pathway (Abdelmegeid et al., 2017; Batistel et al., 2018; Lopreiato et al., 2019).

\section{Cytokine Release in Response to Chol and Met Supply}

Tumor necrosis factor- $\alpha$, IL-1 $\beta$, and IL- 6 are described as proinflammatory cytokines and are directly related to increased inflammatory responses in dairy cows (Esposito et al., 2014; Trevisi et al., 2015). However, the lack of published data on these cytokines in the context of PMN challenge with HS renders discussion of our data challenging. In the Met experiment, we detected a relationship between abundance of IL 6 and amount of IL-6 in the medium. In fact, a quadratic effect indicated that the highest concentrations were achieved at a Lys:Met ratio of 2.9:1 during HS, which agreed with the mRNA fold-change data for IL6. It is noteworthy, however, that in a previous study with dairy cows undergoing a long-term heat stress challenge, plasma TNF- $\alpha$ and IL-6 increased (Min et al., 2016). Although in vitro data do not always mirror the in vivo response, regulation of cytokine synthesis does not occur strictly at the mRNA level. This idea is supported by the reduction of IL-1 $\beta$ and TNF- $\alpha$ concentrations during HS compared with TN in the experiment with Chol. It is likely that posttranslational mechanisms are involved in determining cytokine production, particularly in the short term, due to a given biological challenge.

\section{Methionine Cycle and Transsulfuration Pathway Response to Chol and Met Supply}

Activity of cystathionine $\beta$-synthase (CBS) in the first reaction of the transsulfuration pathway uses homocysteine to synthesize cystathionine, which is followed by cystathionine gamma-lyase $(\mathrm{CTH})$ that results in release of cysteine (Banerjee et al., 2003). The latter undergoes metabolism through 2 pathways to synthesize antioxidants: (1) taurine, which involves activation of cysteine dioxygenase (CDO1) and cysteine sulfinic acid decarboxylase (CSAD); and (2) glutathione (GSH) by the action of glutamate-cysteine ligase catalytic subunit (GCLC), and glutathione synthase (GSS) (Park et al., 2017).

Although supply of Met led only to greater upregulation of CDO1 at the highest dose (Lys:Met 2.4:1), we speculate that the greater overall fold-change in abundance of genes encoding enzymes of the transsulfuration pathway in PMN supplemented with Chol at $400 \mu \mathrm{g} / \mathrm{mL}$ indicated greater activation of the system 


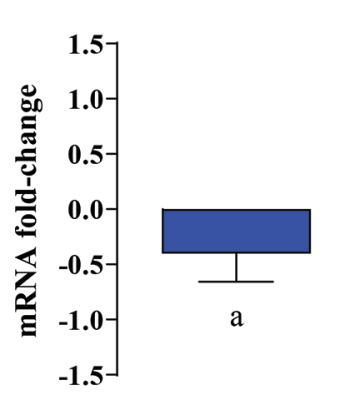

$\boldsymbol{B} \boldsymbol{A} \boldsymbol{X}$

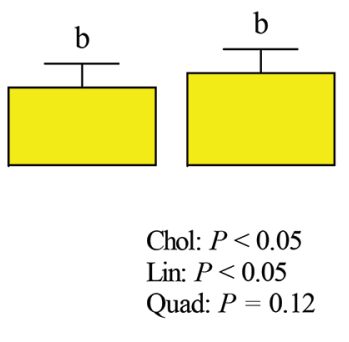

BCL2
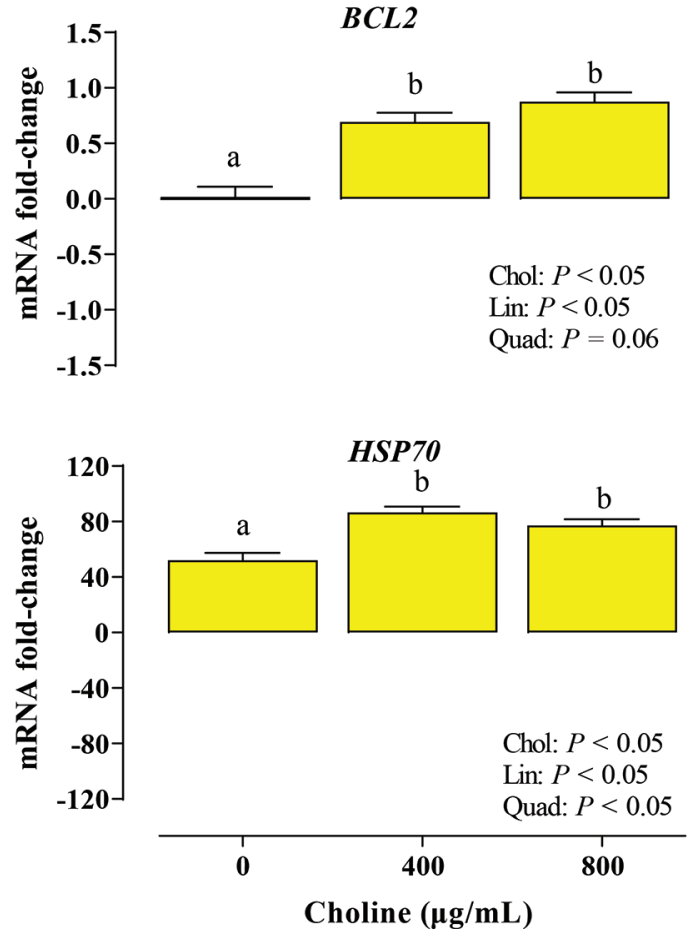

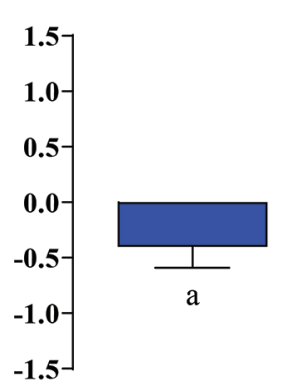

$B A X$

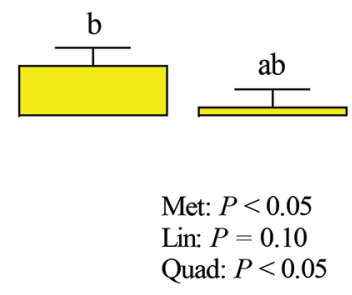

$B C L 2$
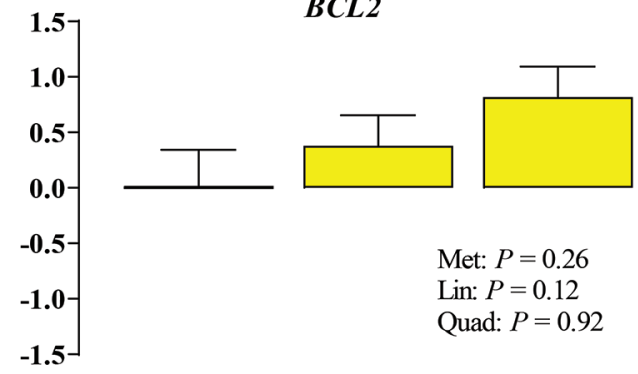

Met: $P=0.26$

Lin: $P=0.12$

Quad: $P=0.92$

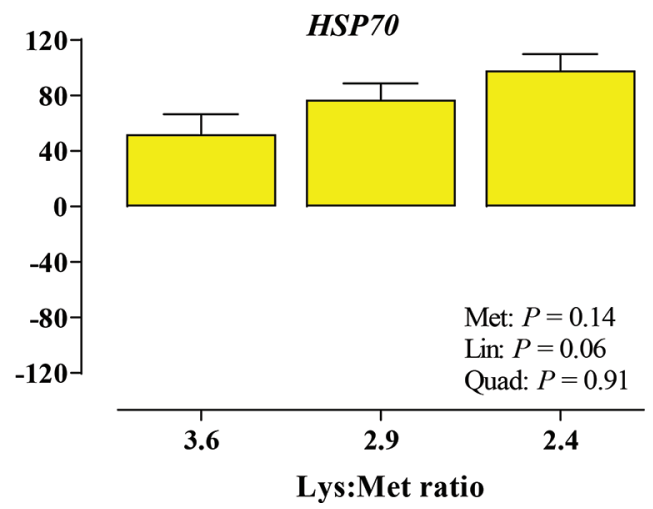

Figure 5. Effect of different in vitro levels of choline (Chol; 0, 400, and $800 \mu \mathrm{g} / \mathrm{mL}$ ) and Lys:Met ratios (Met; 3.6:1, 2.9:1, and 2.4:1) during a heat stress challenge $\left(42^{\circ} \mathrm{C}, \mathrm{HS}\right)$ on mRNA abundance of genes related to apoptosis regulation and cellular stress response $(B A X, B C L 2$, and $\mathrm{HSP}^{70}$ ) in PMN cultures isolated from mid-lactating dairy cows. Data are expressed as fold-change relative to a thermo-neutral temperature $\left(37^{\circ} \mathrm{C}, \mathrm{TN}\right)$. Yellow bars indicate upregulation, whereas blue bars indicate downregulation due to HS challenge within each treatment relative to TN. Error bars represent SEM of the model estimate. Means with different letters (a, b) differ at $P \leq 0.10$.

toward production of taurine and GSH when cells experienced heat stress. It is possible, however, that despite downregulation of $C B S$ during heat stress and lower fold-change in abundance with Chol at $800 \mu \mathrm{g} /$ $\mathrm{mL}$, upregulation of the other enzymes in the pathway compensated for this effect. The lower fold-change in abundance of $C B S$ at $800 \mu \mathrm{g}$ of $\mathrm{Chol} / \mathrm{mL}$ agreed with the fold-change in abundance of $S A H H$, a response that might have represented negative feedback signaling of PMN to counteract potentially excessive accumulation of homocysteine, which becomes toxic at high concentrations and causes unwanted activation of the immune system (Boldyrev et al., 2013). Although data from the present study cannot fully explain the modest responses to supply of Met, the greater upregulation of CDO1 at the highest dose of Met might have been associated with cellular needs for taurine, hypotaurine, and sulfate, or simply to regulate intracellular concentrations of cysteine.

Concerning the pathways that allow the production of taurine and GSH, early studies underscored the importance of GSH in protecting neutrophils against their own toxic metabolites (Scott et al., 1990). Imbalances in the PMN redox system lead to dysfunction in the bactericidal capacity of PMN, probably because of oxidative stress damage (Lubos et al., 2011). Similar to GSH, taurine is another potent sulfur-containing antioxidant. Taurine has also been shown to have a 
protective effect on oxidative burst capability of PMN (Chorąży et al., 2002; Ekremoğlu et al., 2007). In fact, studies have demonstrated that taurine enhances neutrophil phagocytosis and oxidative burst capabilities upon a biological challenge (Chorąży et al., 2002; Erdamar et al., 2007). Hence, sulfur-containing antioxidant (GSH and taurine) concentration and metabolism appear to be essential for PMN to mount effective protection (phagocytosis and oxidative burst) against invading pathogens. At the same time, those events offer a "self-protecting" mechanism against free radicals and reactive oxygen species (ROS) produced when PMN are activated.

Overall, results from the present study confirmed, in part, our previous research with PMN from calves and mid-lactating cows (Abdelmegeid et al., 2017; Lopreiato et al., 2019). In particular, the greater fold-change in abundance of GPX1 in response to Chol supply during HS would be beneficial to PMN. Glutathione peroxidase-1 (GPx-1) is an intracellular antioxidant enzyme that enzymatically reduces hydrogen peroxide to water to limit its harmful effects. Certain ROS, such as hydrogen peroxide, are also essential for growth factormediated signal transduction, mitochondrial function, and maintenance of normal thiol redox balance. Thus, by limiting hydrogen peroxide accumulation, GPx-1 also modulates these processes (Lubos et al., 2011).

The effect on GPX1 and GSR when supply of Chol increased was likely linked with the response in SOD1. This gene encodes the enzyme superoxide dismutase, which plays a major role in the formation of hydrogen peroxide (Lubos et al., 2011). The greater fold-change in abundance of $S O D 1$ in response to Chol supply supports the notion of better coordination of mechanisms related to the immune response and antioxidant systems in restoring the redox balance when cells were challenged by HS. Thus, greater upregulation of GSS, $G S R$, and GPX1 in response to Chol supply during HS could have been linked to the fact that, in the presence of Chol, the PMN were able to activate production of GSH to a greater extent via activation of GSS. Under that scenario, greater availability of GSH could have enhanced its oxidation via GPx-1 to glutathione disulfide (GSSG) in the reaction that eliminates ROS, and also reduction of GSSG to GSH for use by GPx-1 (Lubos et al., 2011; Lushchak, 2012).

Previous studies in murine and human models demonstrated that increased glutathione activity was associated with improved innate immune response against bacterial infection, particularly greater production of neutrophil extracellular traps, oxidative burst, and phagocytosis activity (Loos et al., 1976; Yan et al., 2012). Despite the lack of statistical significance, the pattern of GSS and GSR observed with Met supply was similar to that of Chol, suggesting a potentially similar mechanism of action. In addition, this finding could be corroborated by previous research undertaken by our group, where rumen-protected Met supply to obtain a Lys:Met ratio of 2.8:1 or 2.9:1 in the MP of periparturient Holstein dairy cows led to greater concentration of total plasma GSH and reduced GSH, increased phagocytosis activity, and increased oxidative burst in PMN (Zhou et al., 2016a; Batistel et al., 2018).

Overall, results provide evidence that under a heat stress challenge, Met and, in particular, Chol supply can help PMN maintain or improve antioxidant mechanisms as reported previously in nonchallenged PMN cultures (Abdelmegeid et al., 2017; Lopreiato et al., 2019) and in PMN isolated from cows supplemented with either Met or Chol (Zhou et al., 2018). In addition, a previous study with heat-stressed broilers demonstrated that acute HS and higher Met supply upregulated $C B S, G S S$, and $G P X^{7} 7$ (Del Vesco et al., 2015). Thus, results suggest that cells attempt to avoid excessive ROS production by upregulating genes that are part of or contribute to the antioxidant system.

\section{Inflammation and Immune Pathway Response to Chol and Met Supply}

The impairment of bovine leukocyte function during HS is well known (Lacetera et al., 2006; do Amaral et al., 2011; Catozzi et al., 2020). In general, upon infection or presence of chemoattractants (e.g., proinflammatory cytokines), circulating neutrophils, after rolling, adhering, and crossing the endothelial barrier, migrate toward the infection (Moyes et al., 2010; El-Benna et al., 2016). Adhesion molecules, therefore, play key roles in the recruitment of PMN to the site of infection and subsequent inflammatory and immune responses. Various genes participate in the adhesion and migration of PMN. Among those, the marked greater upregulation of CXCR1 and SELL to Chol supply at $400 \mu \mathrm{g} / \mathrm{mL}$ during HS indicated a more activated state of PMN in terms of adhesion and migration. The overall greater fold-change in abundance of these genes in response to Chol supply agreed with that of inflammation-related genes (IL1B, IL10, IRAK1, NFKB1, TLR2, and $T L R 4)$. Thus, together, these data suggest that greater activation of PMN was associated with enhanced overall inflammatory and immune response coupled with antibacterial responses ( $L Y Z, M P O$, and $H L A A)$.

Support for the idea that Chol induced greater overall activation of PMN are data from one of our recent studies in which isolated PMN supplemented with Met with or without Chol in vitro had greater mRNA abundance of TLR4 and SELL, which are involved in pathogen recognition and cell-adhesion mechanisms for 
extravasation through endothelial cells into infected tissues, respectively (Lopreiato et al., 2019). Concerning the response of pattern recognition receptors (i.e., TLR), our data are consistent with those of Garcia et al. (2018) in isolated PMN from lactating Holstein cows supplemented in vitro with Chol at 8 or $13 \mu \mathrm{M}$. Indeed, an increase in Chol supply led to a greater upregulation of TLR 4, which authors suggested emphasized its role in regulating the inflammatory response of immune cells, especially when external stressors such as HS occur and challenge cellular homeostasis.

The toll-like receptors are pivotal during the innate immune response against pathogens, because they recognize foreign non-self material and trigger the innate inflammatory response through activation of nuclear factor $(\mathrm{NF})-\kappa \mathrm{B}$, which in turn leads to upregulation of an array of inflammatory cytokines (Taraktsoglou et al., 2011). Hence, expression of an increased number of pattern recognition receptors and their downstream activation of IRAK1 and NF- $\mathrm{BB}$ signaling is likely to be beneficial, especially under HS, a well-known effector of immune dysfunction. In fact, their signaling rapidly induces various inflammatory cytokines and chemokines, consequently triggering an array of antimicrobial immune responses (Kumar et al., 2011; Heiser et al., 2018).

Despite the clear activation of PMN upon HS challenge in response to Chol supply, data also indicated the existence of a feedback mechanism to contain such activation, a response that can be surmised by the higher fold-change in abundance of IL10 and NRC31, both of which have potent anti-inflammatory effects counteracting the expression of proinflammatory cytokines (Couper et al., 2008; Chinenov et al., 2013). Regardless of Chol or Met supply, it is noteworthy to highlight the consistency of the IL10 response in the present study with that reported by Catozzi et al. (2020) in heat-stressed monocytes in vitro and demonstrating a downregulation of IL10.

\section{Cellular Stress Response to Chol and Met Supply}

The greater fold-change in abundance of $\mathrm{HSP}^{\mathrm{r}} \mathrm{O}$ in response to increased supply of $\mathrm{Chol}$ and Met suggested that under HS conditions these nutrients could be channeled toward synthesis of proteins that serve a protective role. Such a role has been reported for Met because it can increase heat shock protein (Hsp) abundance during HS, oxidative stress, and other stress states in cells or tissues (Han et al., 2015), but also in unstimulated PMN (Lopreiato et al., 2019). Several studies have reported upregulation in terms of mRNA and protein abundance of Hsp under HS in PMN, monocytes, lymphocytes, and immortalized mammary alveolar cells (Lacetera et al., 2006; Basiricò et al., 2011; Salama et al., 2019; Catozzi et al., 2020). In addition, previous studies have shown a specific association between the presence of Hsp70 and thermo-tolerance mechanisms in various cell types (Hunter-Lavin et al., 2004).

The various Hsp function as molecular chaperones in restoring cellular homeostasis and promoting cell survival. Several studies in mice, bovine, and human cells have provided evidence that constitutive increases of the inducible Hsp at the mRNA and protein level upon HS provide cytoprotection (Horowitz, 2001; Collier et al., 2006). In particular, upon HS, Hsp70 represents the most highly inducible Hsp, being vitally important for thermo-tolerance in cell culture, and intervening in cell death by downregulating apoptotic signaling within the cell through its interaction with BAX (Bcl-2-associated $\mathrm{X}$ protein), a pro-apoptotic signaling protein (Steel, 2004; Stankiewicz et al., 2005). Heat shock proteins can also have a direct effect on NF- $\kappa \mathrm{B}$ activation, with some studies reporting inhibition of the activation of NF- $\kappa B$ in murine Küpffer cells and macrophages (Schell et al., 2005; Sun et al., 2005), and others reporting a stimulatory, direct, cytokine-like effect on the innate immune system; that is, acting as danger-signaling molecules (Wallin et al., 2002; Tsan and Gao, 2004). These opposite effects are explained by the fact that intracellularly, Hsp (as molecular chaperones) bind to $\mathrm{IkB}$, inhibiting its degradation (required to activate the translocation of NF- $\kappa$ B into nucleus; Schell et al., 2005), but in the extracellular environment they can be recognized (i.e., serve as endogenous ligands) via CD14/TLR2 and TLR4 complex, leading to activation of NF- $\kappa \mathrm{B}$ (Tsan and Gao, 2004). The present data, albeit at the mRNA level, revealed a clear upregulation in NF- $\kappa \mathrm{B}$ signaling of PMN upon HS challenge in response to Chol and Met supply, which led us to hypothesize that supply of both nutrients (Chol in particular) not only increased production of Hsp70 but also its availability in the extracellular environment. Further research assessing translational and posttranslational regulation is warranted to address this hypothesis. This is particularly important because for $N F K B 1$, for example, mRNA abundance alone is not sufficient to evaluate increases or decreases in activation, partly because the I $\kappa \mathrm{B}$ proteins represent one of the primary means of NF- $\kappa \mathrm{B}$ regulation (Oeckinghaus and Ghosh, 2009).

Although a large number of genes are involved in the regulation of apoptotic cell death, BCL2 and related family member $B A X$ play a major role during inflammation (Nakamura, 2000). Thus, the greater foldchange in abundance of $B C L 2$ and $B A X$ with Chol and Met during HS led us to speculate that these nutrients were effective in triggering antiapoptotic and proapop- 
totic signals. At least for $B A X$, a possible mechanism whereby Met, and especially Chol, altered its abundance could be related to activation of the immune system and the ensuing increase in the production of free radicals and ROS (suggested by the MPO and SOD1 response). However, the fact that $\mathrm{Chol}$ and Met had a positive effect on taurine and glutathione pathways (antioxidant enzymes) also suggests that both nutrients could be effective at providing some protection against cellular damage, in large part through antioxidant action (Osorio et al., 2014; Lopreiato et al., 2019).

\section{CONCLUSIONS}

In the era of immunometabolism, supplying functional nutrients is receiving intense focus among animal scientists in an attempt to positively modulate mechanisms underpinning immune responses when a physiological challenge arises. The current data suggest that the supply of Chol and Met during thermal stress conditions exerts a concerted enhancement of PMN gene networks associated with antioxidant systems (protecting vital cellular process from free radicals and ROS), inflammatory mediators, and immune response. Thus, these modulatory effects underscore the possibility of enhancing the postruminal supply of Met and, in particular, Chol during thermal stress. Clearly, further research will be needed to assess in vivo the beneficial doses in the context of PMN immunological activity and function during periods of thermal stress.

\section{ACKNOWLEDGMENTS}

M. Vailati-Riboni was supported in part by Hatch funds under project ILLU-538-914, National Institute of Food and Agriculture (Washington, DC). The authors declare no conflict of interest.

\section{REFERENCES}

Abdelmegeid, M. K., M. Vailati-Riboni, A. Alharthi, F. Batistel, and J. J. Loor. 2017. Supplemental methionine, choline, or taurine alter in vitro gene network expression of polymorphonuclear leukocytes from neonatal Holstein calves. J. Dairy Sci. 100:3155-3165. https://doi.org/10.3168/jds.2016-12025.

Aggarwal, A., and R. Upadhyay. 2013. Heat Stress and Immune Function. Springer India, New Delhi, India.

Armentano, L. E., S. J. Bertics, and G. A. Ducharme. 1997. Response of lactating cows to methionine or methionine plus lysine added to high protein diets based on alfalfa and heated soybeans. J. Dairy Sci. 80:1194-1199. https://doi.org/10.3168/jds.S0022 -0302(97)76047-8.

Banerjee, R., R. Evande, Ö. Kabil, S. Ojha, and S. Taoka. 2003. Reaction mechanism and regulation of cystathionine $\beta$-synthase. Biochim. Biophys. Acta. 1647:30-35. https://doi.org/10.1016/S1570 -9639(03)00044-X.

Basiricò, L., P. Morera, V. Primi, N. Lacetera, A. Nardone, and U. Bernabucci. 2011. Cellular thermotolerance is associated with heat shock protein 70.1 genetic polymorphisms in Holstein lactating cows. Cell Stress Chaperones 16:441-448. https://doi.org/10 $.1007 / \mathrm{s} 12192-011-0257-7$.

Batistel, F., J. M. Arroyo, A. Bellingeri, L. Wang, B. Saremi, C. Parys, E. Trevisi, F. C. Cardoso, and J. J. Loor. 2017. Ethyl-cellulose rumen-protected methionine enhances performance during the periparturient period and early lactation in Holstein dairy cows. J. Dairy Sci. 100:7455-7467. https://doi.org/10.3168/jds.2017-12689.

Batistel, F., J. M. Arroyo, C. I. M. Garces, E. Trevisi, C. Parys, M. A. Ballou, F. C. Cardoso, and J. J. Loor. 2018. Ethyl-cellulose rumen-protected methionine alleviates inflammation and oxidative stress and improves neutrophil function during the periparturient period and early lactation in Holstein dairy cows. J. Dairy Sci. 101:480-490. https://doi.org/10.3168/jds.2017-13185.

Baumgard, L. H., and R. P. Rhoads Jr.. 2013. Effects of heat stress on postabsorptive metabolism and energetics. Annu. Rev. Anim. Biosci. 1:311-337. https://doi.org/10.1146/annurev-animal-031412 -103644 .

Bernabucci, U., S. Biffani, L. Buggiotti, A. Vitali, N. Lacetera, and A. Nardone. 2014. The effects of heat stress in Italian Holstein dairy cattle. J. Dairy Sci. 97:471-486. https://doi.org/10.3168/jds.2013 $-6611$.

Bernabucci, U., N. Lacetera, L.H. Baumgard, R.P. Rhoads, B. Ronchi, and A. Nardone. 2010. Metabolic and hormonal acclimation to heat stress in domesticated ruminants. Animal 4:1167-1183. https: //doi.org/10.1017/S175173111000090X.

Boldyrev, A., E. Bryushkova, A. Mashkina, and E. Vladychenskaya. 2013. Why is homocysteine toxic for the nervous and immune systems? Curr. Aging Sci. 6:29-36. https://doi.org/10.2174/ 18746098112059990007.

Catozzi, C., G. Ávila, V. Zamarian, D. Pravettoni, G. Sala, F. Ceciliani, N. Lacetera, and C. Lecchi. 2020. In vitro effect of heat stress on bovine monocytes lifespan and polarization. Immunobiology 225:151888. https://doi.org/10.1016/j.imbio.2019.11.023.

Chinenov, Y., R. Gupte, and I. Rogatsky. 2013. Nuclear receptors in inflammation control: Repression by GR and beyond. Mol. Cell. Endocrinol. 380:55-64. https://doi.org/10.1016/j.mce.2013.04.006.

Chorąży, M., E. Kontny, J. Marcinkiewicz, and W. Maśliński. 2002. Taurine chloramine modulates cytokine production by human peripheral blood mononuclear cells. Amino Acids 23:407-413. https: //doi.org/10.1007/s00726-002-0204-0.

Coleman, D. N., V. Lopreiato, A. S. Alharthi, and J. J. Loor. 2020. Amino acids and the regulation of oxidative stress and immune function in dairy cattle. J. Anim. Sci. 98:S175-S193. https://doi .org/10.1093/jas/skaa138.

Collier, R. J., C. M. Stiening, B. C. Pollard, M. J. VanBaale, L. H. Baumgard, P. C. Gentry, and P. M. Coussens. 2006. Use of gene expression microarrays for evaluating environmental stress tolerance at the cellular level in cattle. J. Anim. Sci. 84(Suppl_13):E1E13. https://doi.org/10.2527/2006.8413_supplE1x.

Couper, K. N., D. G. Blount, and E. M. Riley. 2008. IL-10: The master regulator of immunity to infection. J. Immunol. 180:5771-5777. https://doi.org/10.4049/jimmunol.180.9.5771.

Del Vesco, A. P., E. Gasparino, D. O. Grieser, V. Zancanela, M. A. M. Soares, and A. R. de Oliveira Neto. 2015. Effects of methionine supplementation on the expression of oxidative stress-related genes in acute heat stress-exposed broilers. Br. J. Nutr. 113:549-559. https://doi.org/10.1017/S0007114514003535.

do Amaral, B. C., E. E. Connor, S. Tao, M. J. Hayen, J. W. Bubolz, and G. E. Dahl. 2011. Heat stress abatement during the dry period influences metabolic gene expression and improves immune status in the transition period of dairy cows. J. Dairy Sci. 94:86-96. https://doi.org/10.3168/jds.2009-3004.

Ekremoğlu, M., N. Türközkan, H. Erdamar, Y. Kurt, and H. Yaman. 2007. Protective effect of taurine on respiratory burst activity of polymorphonuclear leukocytes in endotoxemia. Amino Acids 32:413-417. https://doi.org/10.1007/s00726-006-0382-2.

El-Benna, J., M. Hurtado-Nedelec, V. Marzaioli, J. C. Marie, M. A. Gougerot-Pocidalo, and P. M. Dang. 2016. Priming of the neutrophil respiratory burst: Role in host defense and inflammation. Immunol. Rev. 273:180-193. https://doi.org/10.1111/imr.12447. 
Erdamar, H., N. Türközkan, M. Ekremoğlu, Y. Kurt, and H. Yaman. 2007. The effect of taurine on polymorphonuclear leukocyte functions in endotoxemia. Amino Acids 33:581-585. https://doi.org/10 .1007/s00726-007-0543-y.

Esposito, G., P. C. Irons, E. C. Webb, and A. Chapwanya. 2014. Interactions between negative energy balance, metabolic diseases, uterine health and immune response in transition dairy cows. Anim. Reprod. Sci. 144:60-71. https://doi.org/10.1016/j.anireprosci.2013 .11 .007 .

Fear, J. M., and P. J. Hansen. 2011. Developmental changes in expression of genes involved in regulation of apoptosis in the bovine preimplantation embryo. Biol. Reprod. 84:43-51. https://doi.org/ 10.1095/biolreprod.110.086249.

Futosi, K., S. Fodor, and A. Mócsai. 2013. Neutrophil cell surface receptors and their intracellular signal transduction pathways. Int. Immunopharmacol. 17:638-650. https://doi.org/10.1016/j.intimp .2013.06.034.

Gao, S. T., J. Guo, S. Y. Quan, X. M. Nan, M. V. S. Fernandez, L. H. Baumgard, and D. P. Bu. 2017. The effects of heat stress on protein metabolism in lactating Holstein cows. J. Dairy Sci. 100:5040-5049. https://doi.org/10.3168/jds.2016-11913.

Garcia, M., L. K. Mamedova, B. Barton, and B. J. Bradford. 2018. Choline regulates the function of bovine immune cells and alters the mRNA abundance of enzymes and receptors involved in its metabolism in vitro. Front. Immunol. 9:2448. https://doi.org/10 .3389/fimmu.2018.02448.

Han, Z.-Y., T. Mu, and Z. Yang. 2015. Methionine protects against hyperthermia-induced cell injury in cultured bovine mammary epithelial cells. Cell Stress Chaperones 20:109-120. https://doi.org/ 10.1007/s12192-014-0530-7.

Heiser, A., S. J. LeBlanc, and S. McDougall. 2018. Pegbovigrastim treatment affects gene expression in neutrophils of pasture-fed, periparturient cows. J. Dairy Sci. 101:8194-8207. https://doi.org/ $10.3168 /$ jds.2017-14129.

Horowitz, M. 2001. Heat acclimation: Phenotypic plasticity and cues to the underlying molecular mechanisms. J. Therm. Biol. 26:357363. https://doi.org/10.1016/S0306-4565(01)00044-4.

Hunter-Lavin, C., E. L. Davies, M. M. F. V. G. Bacelar, M. J. Marshall, S. M. Andrew, and J. H. H. Williams. 2004. Hsp70 release from peripheral blood mononuclear cells. Biochem. Biophys. Res. Commun. 324:511-517. https://doi.org/10.1016/j.bbrc.2004.09 .075 .

Hyder, I., P. Ravi Kanth Reddy, J. Raju, P. Manjari, C. Srinivasa Prasad, K. Aswani Kumar, and V. Sejian. 2017. Alteration in Rumen Functions and Diet Digestibility During Heat Stress in Sheep. Springer Singapore, Singapore.

Ingvartsen, K. L., and K. Moyes. 2013. Nutrition, immune function and health of dairy cattle. Animal 7:112-122. https://doi.org/10 .1017/S175173111200170X.

Joshi, B. C., H. B. Joshi, R. E. McDowell, and D. P. Sadhu. 1968. Composition of skin secretions from three Indian breeds of cattle under thermal stress. J. Dairy Sci. 51:917-920. https://doi.org/10 $.3168 /$ jds.S0022-0302(68)87105-X.

Kobayashi, S. D., and F. R. DeLeo. 2009. Role of neutrophils in innate immunity: A systems biology-level approach. Wiley Interdiscip. Rev. Syst. Biol. Med. 1:309-333. https://doi.org/10.1002/wsbm .32 .

Kumar, H., T. Kawai, and S. Akira. 2011. Pathogen recognition by the innate immune system. Int. Rev. Immunol. 30:16-34. https://doi .org/10.3109/08830185.2010.529976.

Lacetera, N., U. Bernabucci, L. Basiricò, P. Morera, and A. Nardone. 2009. Heat shock impairs DNA synthesis and down-regulates gene expression for leptin and $\mathrm{Ob}-\mathrm{Rb}$ receptor in concanavalin A-stimulated bovine peripheral blood mononuclear cells. Vet. Immunol. Immunopathol. 127:190-194. https://doi.org/10.1016/j.vetimm 2008.09.020.

Lacetera, N., U. Bernabucci, D. Scalia, L. Basiricò, P. Morera, and A. Nardone. 2006. Heat stress elicits different responses in peripheral blood mononuclear cells from Brown Swiss and Holstein cows. J. Dairy Sci. 89:4606-4612. https://doi.org/10.3168/jds.S0022 -0302(06)72510-3.
Lecchi, C., N. Rota, A. Vitali, F. Ceciliani, and N. Lacetera. 2016. In vitro assessment of the effects of temperature on phagocytosis, reactive oxygen species production and apoptosis in bovine polymorphonuclear cells. Vet. Immunol. Immunopathol. 182:89-94. https:/ /doi.org/10.1016/j.vetimm.2016.10.007.

Loos, H., D. Roos, R. Weening, and J. Houwerzijl. 1976. Familial deficiency of glutathione reductase in human blood cells. Blood 48:53-62. https://doi.org/10.1182/blood.V48.1.53.53.

Lopreiato, V., M. Vailati-Riboni, A. Bellingeri, I. Khan, G. Farina, C. Parys, and J. J. Loor. 2019. Inflammation and oxidative stress transcription profiles due to in vitro supply of methionine with or without choline in unstimulated blood polymorphonuclear leukocytes from lactating Holstein cows. J. Dairy Sci. 102:10395-10410. https://doi.org/10.3168/jds.2019-16413.

Lubos, E., J. Loscalzo, and D. E. Handy. 2011. Glutathione peroxidase-1 in health and disease: From molecular mechanisms to therapeutic opportunities. Antioxid. Redox Signal. 15:1957-1997. https: //doi.org/10.1089/ars.2010.3586.

Lushchak, V. I. 2012. Glutathione homeostasis and functions: Potential targets for medical interventions. J. Amino Acids 2012:736837. https://doi.org/10.1155/2012/736837.

McGuire, M. A., D. K. Beede, M. A. DeLorenzo, C. J. Wilcox, G. B. Huntington, C. K. Reynolds, and R. J. Collier. 1989. Effects of thermal stress and level of feed intake on portal plasma flow and net fluxes of metabolites in lactating Holstein cows. J. Anim. Sci 67:1050-1060. https://doi.org/10.2527/jas1989.6741050x.

Min, L., N. Zheng, S. Zhao, J. Cheng, Y. Yang, Y. Zhang, H. Yang, and J. Wang. 2016. Long-term heat stress induces the inflammatory response in dairy cows revealed by plasma proteome analysis. Biochem. Biophys. Res. Commun. 471:296-302. https://doi.org/10 .1016/j.bbrc.2016.01.185.

Moyes, K. M., J. K. Drackley, D. E. Morin, and J. J. Loor. 2010. Greater expression of TLR2, TLR4, and IL6 due to negative energy balance is associated with lower expression of HLA-DRA and HLA-A in bovine blood neutrophils after intramammary mastitis challenge with Streptococcus uberis. Funct. Integr. Genomics 10:53-61. https://doi.org/10.1007/s10142-009-0154-7.

Moyes, K. M., D. E. Graugnard, M. J. Khan, M. Mukesh, and J. J. Loor. 2014. Postpartal immunometabolic gene network expression and function in blood neutrophils are altered in response to prepartal energy intake and postpartal intramammary inflammatory challenge. J. Dairy Sci. 97:2165-2177. https://doi.org/10.3168/jds .2013-7433.

Nakamura, M. 2000. Preconditioning decreases Bax expression, PMN accumulation and apoptosis in reperfused rat heart. Cardiovasc. Res. 45:661-670. https://doi.org/10.1016/S0008-6363(99)00393-4.

NRC (National Research Council). 2001. Nutrient Requirements of Dairy Cattle. 7th ed. National Academies Press, Washington, DC.

Oeckinghaus, A., and S. Ghosh. 2009. The NF- $\kappa$ B family of transcription factors and its regulation. Cold Spring Harb. Perspect. Biol. 1:a000034. https://doi.org/10.1101/cshperspect.a000034.

Osorio, J. S., P. Ji, J. K. Drackley, D. Luchini, and J. J. Loor. 2014. Smartamine M and MetaSmart supplementation during the peripartal period alter hepatic expression of gene networks in 1-carbon metabolism, inflammation, oxidative stress, and the growth hormone-insulin-like growth factor 1 axis pathways. J. Dairy Sci. 97:7451-7464. https://doi.org/10.3168/jds.2014-8680.

Park, E., S. Y. Park, I. S. Cho, B. S. Kim, and G. Schuller-Levis. 2017. A novel cysteine sulfinic acid decarboxylase knock-out mouse: Taurine distribution in various tissues with and without taurine supplementation. D. H. Lee, S. W. Schaffer, E. Park, and H. W. Kim, ed. Taurine 10. Advances in Experimental Medicine and Biology, Vol. 975. Springer, Dordrecht, Germany. https://doi.org/ https://doi.org/10.1007/978-94-024-1079-2_37.

Salama, A. A. K., G. Caja, S. Hamzaoui, B. Badaoui, A. CastroCosta, D. A. E. Façanha, M. M. Guilhermino, and R. Bozzi. 2014 Different levels of response to heat stress in dairy goats. Small Rumin. Res. 121:73-79. https://doi.org/10.1016/j.smallrumres.2013 .11 .021 .

Salama, A. A. K., M. Duque, L. Wang, K. Shahzad, M. Olivera, and J. J. Loor. 2019. Enhanced supply of methionine or arginine al- 
ters mechanistic target of rapamycin signaling proteins, messenger RNA, and microRNA abundance in heat-stressed bovine mammary epithelial cells in vitro. J. Dairy Sci. 102:2469-2480. https:/ /doi.org/10.3168/jds.2018-15219.

Schell, M. T., A. L. Spitzer, J. A. Johnson, D. Lee, and H. W. Harris. 2005. Heat shock inhibits NF-kB activation in a dose- and time-dependent manner. J. Surg. Res. 129:90-93. https://doi.org/ 10.1016/j.jss.2005.05.025.

Scott, R. B., S. Matin, and S. C. Hamilton. 1990. Glutathione, glutathione S-transferase, and transmembrane transport of glutathione conjugate in human neutrophil leukocytes. J. Lab. Clin. Med. 116:674-680.

Silanikove, N. 2000. Effects of heat stress on the welfare of extensively managed domestic ruminants. Livest. Prod. Sci. 67:1-18. https:// doi.org/10.1016/S0301-6226(00)00162-7.

Stankiewicz, A. R., G. Lachapelle, C. P. Z. Foo, S. M. Radicioni, and D. D. Mosser. 2005. Hsp70 inhibits heat-induced apoptosis upstream of mitochondria by preventing Bax translocation. J. Biol. Chem. 280:38729-38739. https://doi.org/10.1074/jbc.M509497200.

Steel, G. J., D. M. Fullerton, J. R. Tyson, and C. J. Stirling. 2004. Coordinated activation of Hsp70 chaperones. Science 303(5654):98101. https://doi.org/10.1126/science.1092287.

Sun, D., D. Chen, B. Du, and J. Pan. 2005. Heat shock response inhibits NF- $\kappa \mathrm{B}$ activation and cytokine production in murine Kupffer cells. J. Surg. Res. 129:114-121. https://doi.org/10.1016/j.jss.2005 .05 .028 .

Taraktsoglou, M., U. Szalabska, D. A. Magee, J. A. Browne, T. Sweeney, E. Gormley, and D. E. MacHugh. 2011. Transcriptional profiling of immune genes in bovine monocyte-derived macrophages exposed to bacterial antigens. Vet. Immunol. Immunopathol. 140:130-139. https://doi.org/10.1016/j.vetimm.2010.12.002.

Trevisi, E., N. Jahan, G. Bertoni, A. Ferrari, and A. Minuti. 2015. Pro-inflammatory cytokine profile in dairy cows: Consequences for new lactation. Ital. J. Anim. Sci. 14:3862. https://doi.org/10 .4081/ijas.2015.3862.

Tsan, M.-F., and B. Gao. 2004. Cytokine function of heat shock proteins. Am. J. Physiol. Cell. Physiol. 286:C739-C744. https://doi .org/10.1152/ajpcell.00364.2003.

Vailati-Riboni, M., T. Xu, B. Qadir, R. Bucktrout, C. Parys, and J. J. Loor. 2019. In vitro methionine supplementation during lipopolysaccharide stimulation modulates immunometabolic gene network expression in isolated polymorphonuclear cells from lactating Holstein cows. J. Dairy Sci. 102:8343-8351. https://doi.org/10.3168/ jds.2018-15737.

Vailati-Riboni, M., Z. Zhou, C. B. Jacometo, A. Minuti, E. Trevisi, D. N. Luchini, and J. J. Loor. 2017. Supplementation with rumen- protected methionine or choline during the transition period influences whole-blood immune response in periparturient dairy cows. J. Dairy Sci. 100:3958-3968. https://doi.org/10.3168/jds.2016 $-11812$.

Wallin, R. P. A., A. Lundqvist, S. H. Moré, A. von Bonin, R. Kiessling, and H.-G. Ljunggren. 2002. Heat-shock proteins as activators of the innate immune system. Trends Immunol. 23:130-135. https:// doi.org/10.1016/S1471-4906(01)02168-8.

Yan, J., X. Meng, L. M. Wancket, K. Lintner, L. D. Nelin, B. Chen, K. P. Francis, C. V. Smith, L. K. Rogers, and Y. Liu. 2012. Glutathione reductase facilitates host defense by sustaining phagocytic oxidative burst and promoting the development of neutrophil extracellular traps. J. Immunol. 188:2316-2327. https://doi.org/10 .4049/jimmunol.1102683.

Zanton, G. I., G. R. Bowman, M. Vázquez-Añón, and L. M. Rode. 2014. Meta-analysis of lactation performance in dairy cows receiving supplemental dietary methionine sources or postruminal infusion of methionine. J. Dairy Sci. 97:7085-7101. https://doi.org/10 $.3168 / j \mathrm{jds} .2014-8220$.

Zhou, Z., O. Bulgari, M. Vailati-Riboni, E. Trevisi, M. A. Ballou, F. C. Cardoso, D. N. Luchini, and J. J. Loor. 2016a. Rumen-protected methionine compared with rumen-protected choline improves immunometabolic status in dairy cows during the peripartal period. J. Dairy Sci. 99:8956-8969. https://doi.org/10.3168/jds.2016 $-10986$.

Zhou, Z., F. Ferdous, P. Montagner, D. N. Luchini, M. N. Corrêa, and J. J. Loor. 2018. Methionine and choline supply during the peripartal period alter polymorphonuclear leukocyte immune response and immunometabolic gene expression in Holstein cows. J. Dairy Sci. 101:10374-10382. https://doi.org/10.3168/jds.2018-14972.

Zhou, Z., M. Vailati-Riboni, E. Trevisi, J. K. Drackley, D. N. Luchini, and J. J. Loor. 2016b. Better postpartal performance in dairy cows supplemented with rumen-protected methionine compared with choline during the peripartal period. J. Dairy Sci. 99:8716-8732. https://doi.org/10.3168/jds.2015-10525.

\section{ORCIDS}

V. Lopreiato ( https://orcid.org/0000-0001-6965-7340

M. Vailati-Riboni 이 https://orcid.org/0000-0002-8854-8702

C. Fernandez @ https://orcid.org/0000-0002-0368-0158

A. Minuti @ https://orcid.org/0000-0002-0617-6571

J. J. Loor @ https://orcid.org/0000-0003-1586-4365 